This item was submitted to Loughborough's Research Repository by the author.

Items in Figshare are protected by copyright, with all rights reserved, unless otherwise indicated.

\title{
Government ideology and economic freedom
}

PLEASE CITE THE PUBLISHED VERSION

https://doi.org/10.1016/j.jce.2020.07.007

PUBLISHER

Elsevier

VERSION

AM (Accepted Manuscript)

PUBLISHER STATEMENT

This paper was accepted for publication in the journal Journal of Comparative Economics and the definitive published version is available at https://doi.org/10.1016/j.jce.2020.07.007.

\section{LICENCE}

CC BY-NC-ND 4.0

\section{REPOSITORY RECORD}

Castro, Vitor, and Rodrigo Martins. 2020. "Government Ideology and Economic Freedom". Loughborough University. https://hdl.handle.net/2134/12674072.v1. 


\title{
Government Ideology and Economic Freedom*
}

\author{
Vítor Castro* \\ Loughborough University and NIPE \\ Rodrigo Martins ^ \\ University of Coimbra and CeBER
}

\begin{abstract}
This paper tests the widespread belief that right-wing governments tend to promote economic freedom while left-wing ones prefer more control over the economy. Using annual data for 106 countries over the period 1975-2015 and a two-step system GMM estimator, this study shows that right-wing governments are indeed more prone to promote economic freedom and to deregulate the economy. It also finds that this effect seems to be stronger in developing/emerging economies than in more developed countries. Moreover, the analysis of the broad dimensions of economic freedom indicates that right-wing governments tend to act by improving monetary soundness and freedom to trade internationally and by easing regulations that restrict entry into markets. Mainstream left-wing governments do not seem to affect economic freedom, however populist left-wing parties, when in office, are found to have a detrimental effect.
\end{abstract}

Keywords: Economic Freedom; Government Ideology; Economic Deregulation; GMM estimation.

JEL classification: C23, H10, K20, P16.

\footnotetext{
* The authors thank Niklas Potrafke, Mark Wohar, the editor and three anonymous referees for their helpful comments and suggestions. This work has been financed by National Funds of the Portuguese Foundation for Science and Technology (FCT) within the projects UIDB/03182/2020 (NIPE) and UIDB/05037/2020 (CeBER).

- School of Business and Economics, Loughborough University, Loughborough, Leicestershire LE11 3 TU, UK. Economic Policies Research Unit (NIPE), University of Minho, Campus of Gualtar, 4710-057 Braga, Portugal. Tel.: +44(0)1509222706; E-mail: v.m.q.castro@lboro.ac.uk

^ Faculty of Economics, University of Coimbra, Av. Dias da Silva 165, 3004-512 Coimbra, Portugal. Centre for Business and Economics Research (CeBER), Av. Dias da Silva 165, 3004-512 Coimbra, Portugal. Tel.: +351239790543; E-mail: rodrigom@fe.uc.pt
} 


\section{Introduction}

There is a common believe that ideologies shape policy debates and choices. A fundamental premise for this is that right-wing parties defend a decentralized economy funded on economic freedom and on the protection of property rights, while left-wing parties tend to the diverge from this scenario. This gave rise to an abundancy of studies analyzing partisan preferences over macroeconomic variables with some degree of success in capturing distinctions between right and left ruling (see, for instance, Alesina et al., 1997; Franzese, 2002). However, hovering above the realm of the macroeconomy, we come across the notion of economic freedom that, in general, stands for the degree to which an economy is a market economy. This landscape in which economic agents operate is shaped by policy decisions and existing institutions.

In today's democracies, political debates and voters' perceptions align significantly with the idea that selecting between right or left governments is a choice between socialism and unrestrained free markets. The idea of partisan preferences over economic freedom has been consolidated by, for example, Margaret Thatcher's and Ronald Reagan's strong support to the concept of free markets. In a more recent case, the expansion in the size and scope of the government under the Obama administration - which included new regulations in areas like finance, health care, and the environment - pushed the United States to its lowest economic freedom score ever in 2017. However, under the Trump administration, America's economic freedom has seen a substantial boost linked to several policy changes that include tax cuts and deregulation. Nevertheless, there are also historical examples that contradict the traditional left-right positioning over market freedom. For instance, Tony Blair's "New Labour" (1997-2007) defended limitations to government involvement in the markets and was open to the idea that the state should not own major industries. Yet the empirical question remains: Do right-wing parties, when in office, actually promote and 
guarantee economic freedom, while left-wing governments are more moderate on this matter? And if so, in which of the major dimensions of economic freedom is ideology relevant? These are important questions, not only from the perspective of the democratic functioning of societies, but also for those studying policy decision making. Additionally, answering these questions is critical for understanding the actual contribution of modern political parties to the organization of contemporary societies, allowing us to assess if the longstanding theoretical debate between free markets and interventionism is indeed reflected in real policy choices.

The main goal of this paper is to provide an empirical answer to these interesting research questions. Some clues can be found in the existing literature, but the number of papers on the subject is scarce and centered at the sub-national level. The present paper goes beyond the strict examination of developed economies and resorts to an extended timeframe of annual data in the empirical analysis. To accomplish the task at hand, annual data are collected for 106 countries over the period 1975-2015 and adequate panel data techniques are used to assess the role of ideology. In addition, it tests other political and economic features such as the relevance of time in office, majority governments and the impact of financial crisis. As a measure for the many aspects of economic freedom, we rely on the aggregate Economic Freedom of the World (EFW) index computed by the Fraser Institute and on the five broad areas that compose it.

This study shows that left-wing governments do not affect economic freedom, unless they are populists. In that case, economic freedom is significantly undermined during their tenure in office. However, right-wing governments clearly conform to the expectations: they are indeed more prone to promote economic freedom and to deregulate the economy. This effect is found to be relatively stronger in their first term in office and in developing/emerging economies than in more developed countries. Furthermore, right-wing governments tend to stimulate economic freedom 
levels mainly through monetary soundness, international trade and by easing regulations that restrict entry into markets. In addition, other factors have also proved to play a relevant role in the economic freedom dynamics observed over the last decades.

The rest of the paper is organized as follows. Section 2 discusses the link between ideology and economic freedom; Section 3 describes the data, variables, and methodology. The empirical analysis and discussion of the results are presented in Section 4. Finally, the last section concludes.

\section{Economic Freedom and government ideology}

The traditional partisan hypothesis depicts right-wing parties as strong believers in the importance of free markets and leftist parties as advocates of market control and state intervention. Consequently, it is expected that countries with a prevalence of right-wing governments improve their levels of economic freedom. Although the right/left cleavage is still very much present in today's political agendas and debates, modern researchers point out that theory and practice may be difficult to align. This is largely due to limitations to economic policy imposed by the current legal and institutional framework (see Acemoglu et al. 2005), rising global competition, and electoral concerns (Nordhaus 1975). As such, the capability and willingness of governments to implement a full array of ideological policies may be diminishing. Structural reforms play an important role in the functioning of markets and in the implementation of ideologically based policies. Several perspectives are proposed to explain what prompts them (see de Haan and Parlevliet, 2018).

The idea put forward by Rodrik (1996) that recessions are important triggers of major policy changes has been confirmed empirically in works by Pitlik and Wirth (2003) and Drazen and Easterly (2001). There is also the suggestion that institutional constraints limiting executive action tend to restrict the execution of major policy changes, however most papers find no empirical 
support for this hypothesis (see, for example, Pitlik and Wirth, 2003). Additionally, reforms may be instigated by a process of policy diffusion across countries, where international policy trends tend to drive local reforms. Employing five-year time spans over the period 1970-2000 for 23 OECD economies, Pitlik (2007) finds that economic policy reforms are influenced by processes of policy diffusion and that market-oriented governments promote economic liberalization.

There is a prevalent belief that governments tend to dislike reforms that exhibit short-term costs, particularly near elections. Opportunism and the electoral cycle should, therefore, lead to fewer reforms. Nevertheless, newly elected governments may be more inclined to policy changes given the distance to the next elections (Alesina et al., 2006) and given the expectations of change they generate on the electorate. Reforms are also expected to be more easily implementable in the context of majority governments. In this paper, we test the importance of these political aspects for economic freedom. We can postulate that if there is a strong policy diffusion along with a global trend reinforcing market liberalization, then the majority context and newly elected governments might end up increasing economic freedom. However, one could argue that the presence of leftwing governments, traditionally adverse to unrestrained free markets, can offset this linkage.

Some authors have begun to explicitly study the importance of economic conditions for party competition with a special focus on globalization constrains to state intervention and on the ideological convergence of mainstream parties (see, for example, Ward et al., 2011). The overall international environmental changes over the last decades have increased the difficulties governments have in implementing ideological agendas, particularly when it comes to left governments trying to carry out fewer liberal policies and simultaneously to capture the median voter. On the one hand, the international trend towards globalization fosters transnational competition, economic integration, and capital mobility, which poses obstacles for policies aimed 
at market control. One the other hand, there is a widespread believe that economic freedom seems to benefit economic prosperity, a policy outcome much appreciated by voters. Gwartney and Lawson (2002) point out that countries in the bottom $20 \%$ of the economic freedom index have had negative growth, while the upper $20 \%$ have grown significantly faster than other countries. Additionally, the causality running from economic freedom to income/growth is reasonably well established (see de Haan et al., 2006). As such, the difficulties faced by electorally constrained left governments, makes us to assume a weaker version of the previous hypothesis, i.e. that the majority context and newly elected governments are, at least, not expected to reduce economic freedom.

The potential barriers to the implementation of the left's agenda are a reason to suspect that, in recent decades, many leftist governments may be unable or unwilling to reduce economic freedom; however, it is not anticipated that they promote it. The constrains work as incentives when thinking of right-wing governments engaging in active pro-market policies. The empirical literature generally recognizes that ideology impacts economic freedom and has emphasized the positive effect of right-wing governments. Focusing on the Canadian provinces, Bjornskov and Potrafke (2012) report that ideology affects labour market regulation. In a similar analysis for the US States, Bjornskov and Potrafke (2013) find further evidence for the impact of ideology on the labour markets, as Republican governors are found to promote deregulation. Furthermore, using a regression discontinuity approach, Hankins and Hoover (2019) find that Democratic governors in the US do not reduce economic freedom when compared to Republican governors elected by a similar margin. Examining the German States, Potrafke (2013) shows that right-wing governments tend to increase economic freedom. However, this evidence was confined to the West German States. Considering a broader group of European Union member states over the period 2000-2012, Jäger (2017) reports that left-wing governments are significantly more likely to restrict economic 
freedom than right-wing governments. In a more recent work, Murphy (2019) uses the Botero et al. (2004) measure of government ideology to predict the EFW index for the years 1995 and 2015. Results also support the dominant view that conservative parties improve economic freedom.

This study goes beyond the strict examination of a country's states or developed economies and resorts to an extended timeframe of annual data. In addition, it also looks at the impact of ideology on the five broad areas of economic freedom.

\section{Data and Methodology}

In this section, we present the data describing the variables and respective sources and provide some descriptive statistics. Then we introduce the methodological approach and the model to be used in the empirical analysis.

\subsection{Data}

To assess the role of the political ideology on economic freedom, we gather annual data for a panel of 106 countries over the period $1975-2015 .{ }^{1}$ Countries were selected according to the availability of economic and political data. This means that we consider only those countries for which there are: (i) economic freedom data for at least a period of five years; (ii) reasonably long series for the main political and socio-economic control variables; (iii) regular/frequent and competitive elections; and (iv) changes in the political orientation of the government over the time period considered in this study.

The Economic Freedom index (EconFreedom) computed by the Fraser Institute is our dependent variable. According to the Economic Freedom of the World 2017 Annual Report

\footnotetext{
${ }^{1}$ The list of countries is provided below in Table 1.
} 
(Gwartney et al., 2017), this index measures the degree to which countries' policies and institutions are supportive of economic freedom. This index ranges from 0 to 10 , with higher values indicating a higher level of economic freedom. The main features that define economic freedom are personal choice, voluntary exchange, freedom to enter markets and compete, and security of the person and of privately owned property. ${ }^{2}$ The dataset comprises information for 159 countries, available annually from 2000 to 2015 and for years ending in zero or five back to 1970 . The data are available for approximately 100 countries back to 1980 . The Fraser Institute uses 42 data points to construct this index (for further details, see Gwartney et al., 2017); it also uses them to measure the degree of economic freedom in five broad areas: Size of Government (SizeGov), Legal System and Property Rights (LegalSystem), Sound Money (SoundMoney), Freedom to Trade Internationally (FreedomTrade), and Regulation (Regulation). ${ }^{3}$

This study aims at assessing the impact of political orientation not only on the overall level of economic freedom but also on each of these more specific areas. To control for this effect, we construct three dummies relying on the EXECRLC variable from the Database of Political Institutions (DPI): Right, Centre, and Left. ${ }^{4}$ These dummies take the value of one when the government if formed by right-wing, centre, or left-wing parties, respectively, and 0 otherwise. $^{5}$

\footnotetext{
${ }^{2}$ Gwartney et al. (2017, p.1) stress that "individuals are economically free when they are permitted to choose for themselves and engage in voluntary transactions as long as they do not harm the person or property of others. [...] economically free individuals will be permitted to decide for themselves rather than having options imposed on them by the political process or the use of violence, theft, or fraud by others."

${ }^{3}$ See Table A.1 in Annex for a more detailed description of these five components.

${ }^{4}$ The DPI divides parties into three groups based on an evaluation of a party's orientation with respect to economic policy (Cruz et al., 2016). For single party majority governments, the indictor variable corresponding to its ideology takes the value one in years during which the party rules a given country. For coalition governments, the DPI classifies a coalition government as having the ideology of the largest coalition partner. The group of right-wing parties includes conservative, Christian democratic, and other right-wing parties; the group of left-wing parties includes communist, socialist, social democratic, and other left-wing parties; and the group of Centre includes parties defined as centrists or which party position can best be described as centrist.

${ }^{5}$ As a robustness check we will also use data from the Comparative Political Data Set (CPDS) to derive an alternative variable for Right. In this case, we consider a right government when the variable GOV_PARTY in CPDS is equal to 1
} 
Looking at the data presented in Figure 1, we observe that the Economic Freedom index is, on average, higher when right-wing parties are in office, both for the period in which the Fraser Institute publishes annual data (2000-2015) and for the period in which DPI data are available (19752015). Plotting the relationship between the Economic Freedom index and the dummy Right, we observe the same positive association (see Figure 2). The linear regression between these two variables stresses the statistical significance of this relationship. ${ }^{6}$ A recent and paradigmatic example of a right-wing government promoting economic freedom (and a left-wing one not) is the US. In the George W. Bush era (2001-2008), the economic freedom index reached an average of 8.3, but during the Barak Obama presidency (2009-2016) it decreased to 7.8.

This initial analysis is very simplistic, hence a more complete specification and proper methodologies are needed to assess the significance of this association. Nevertheless, these preliminary findings are in line with the common understanding that right-wing governments tend to deliver more economic freedom than left-wing ones.

\section{[INSERT FIGURE 1 AROUND HERE]}

\section{[INSERT FIGURE 2 AROUND HERE]}

In order to build an encompassing framework of relevant factors for economic freedom, other variables are added to the model. Some additional political variables - also retrieved from the DPI over the period 1975-2015 - are used to account for the role of the political environment:

or 2 (see Armingeon et al., 2017). The five ideological categories in GOV_PARTY will also be individually analysed. Despite the longer time period (1960-2016), the number of countries for which it is possible to gather political data from this dataset is restricted to: Australia, Austria, Belgium, Bulgaria, Canada, Croatia, Cyprus, Czech Republic, Denmark, Estonia, Finland, France, Germany, Greece, Hungary, Ireland, Italy, Japan, Latvia, Lithuania, Luxembourg, Netherlands, New Zealand, Norway, Poland, Portugal, Romania, Slovak Republic, Slovenia, Spain, Sweden, Switzerland, United Kingdom, United States.

${ }^{6}$ For example, for the period 2000-2015, the observed t-statistic for the coefficient on Right is higher than the $5 \%$ critical value, i.e. $t_{\text {observed }}=0.47439 / 0.0495=9.58>1.96=t_{\text {critical }, 5 \%}$. Hence, the respective estimated coefficient is positive and highly significant. 
- Political cycles in economic freedom are controlled for using a dummy that takes the value of one in the election years (Election), and 0 otherwise.

- Political support is another dimension explored. We use another dummy that takes the value of one when the government has a majority in the parliament (MajGov), and 0 otherwise.

- In addition, we will also assess whether the time a party is in office (TimeOffice) - and respective political orientation - influences the level of economic freedom or not.

- The quality of democracy has been considered in the related literature as one of the conditionings of economic freedom. ${ }^{7}$ Following this literature we use the Democracy variable which corresponds to the "polity2" variable in the POLITY IV database (see Marshall et al., 2017); this measures how democratic a country is in a scale ranging from -10 (strongly autocratic) to 10 (strongly democratic); we anticipate a positive relationship between the quality of democracy and economic freedom.

Following a few studies in the field, we also consider a set of additional socio-economic controllers in our model:

- The level of income is usually associated with economic freedom; while the causality running from economic freedom to income/growth is reasonably well established (de Haan and Sturm, 2000, 2001; de Haan et al., 2006), the opposite is less clear (Farr et al.,1998; Vega-Gordilla and Álvarez -Arce, 2003; Aixalá and Fabro, 2009); we use the real gross domestic product per capita $(G D P p c)$ obtained from World Development Indicators (WDI) dataset to account for the income effect on economic freedom; its five-year average is used to address the any endogeneity issues; we expect GDP per capita to have a positive effect on economic freedom.

\footnotetext{
${ }^{7}$ See, for example, de Haan and Sturm (2003), Lundström (2005); Lipford and Yandle (2015), Krieger and Meierrieks (2016) and Islam (2018).
} 
- Trade openness is another economic factor that can affect economic freedom; countries that are more open to trade are expected to be associated with higher levels of economic freedom; to account for this effect we add to the model the variable Trade computed as exports plus imports as a percentage of GDP and obtained from the WDI. ${ }^{8}$

- Crises are another factor that has been identified as having a negative effect on economic freedom (de Haan et al., 2009; Stocker, 2016; Murphy and Smith, 2017); a dummy that takes the value of one when a financial crises occur is used to account for this effect; financial crises are identified following the works by Laeven and Valencia (2018) and Nguyen et al. (2020).

- Finally, some studies show that the level of education is positively associated with economic freedom (Apergis et al., 2014; Crowley et al., 2017); to account for this effect, we use the Education Index from the 2016 Human Development Report (UNDP, 2016) and expect the same positive relationship; this is consistent with the argument by Caplan (2001) and Caplan and Miller (2010) that higher levels of education yield more liberal economic beliefs.

As a summary, Table 1 presents the list of variables, respective definitions, descriptive statistics, sources, and list of countries used in this study. ${ }^{9}$

\section{[INSERT TABLE 1 AROUND HERE]}

\subsection{Methodology}

The basic statistical analysis provided above in Figures 1 and 2 and the descriptive statistics reported in Table 1 cover two time periods: 2000-2015 and 1975-2015. The reason for this choice

\footnotetext{
${ }^{8}$ This measure, somehow, also reflects the size of a nation as small countries usually have a high trade-to-GDP ratio. Alternatively, we also run some experiments with the KOF globalization index (see Dreher, 2006 and Gygli et al., 2019). Despite the loss some observations/countries when this index is used, the results have proven to be qualitatively and quantitatively identical. Hence, our preference for the standard trade openness measure. These additional results are not reported here but are available upon request.

9 Table A.2 in Annex presents the correlations between all variables.
} 
relies on the data available from the Fraser Institute for the Economic Freedom index and respective areas: annual data are provided for the period 2000-2015, but before 2000 data are available only for years ending in zero or five back to 1970. This creates a problem of missing values and might restrict the econometric analysis to the $2000-2015$ period or even the loss of more observations in case a five-year time span estimation is considered. To overcome this problem, we use King et al. (2001) multiple imputation method to generate the missing data for the period $1970-2000 .{ }^{10}$

As imputation techniques are open to critiques, for obvious reasons, our strategy will always be to compare the results for the period in which we have annual data for economic freedom (20002015) with the ones obtained with the larger sample where (annual) missing values for economic freedom (and respective areas) are generated through the multiple imputation procedure. The following dynamic panel data specification is considered in the estimation for both time periods:

$$
\text { EconFreedom }_{i t}=\rho \text { EconFreedom }_{i t-1}+\beta \text { Right }_{i t}+\boldsymbol{\gamma} \boldsymbol{P o l}_{i t}+\boldsymbol{\delta S o c E c \boldsymbol { S } _ { i t }}+\alpha_{i}+\tau_{t}+\varepsilon_{i t}
$$

where $i=1, \ldots, 106$ and $t=2000, \ldots, 2015$ or $t=1975, \ldots, 2015$ (when imputation is allowed for). ${ }^{11}$ The coefficient on the lag of the dependent variable $(\rho)$ measures its persistence. The coefficient $\beta$ captures the impact of a right-wing government on economic freedom, while the vectors $\boldsymbol{\gamma}$ and $\boldsymbol{\delta}$ assess the effect of the political (Pol) and socio-economic (SocEco) factors described above; $\alpha_{i}$ represents unobserved country-specific effects, while $\tau_{t}$ captures time-effects

\footnotetext{
${ }^{10}$ Following the authors' recommendations, we impute five values for each missing observation and create five complete series for economic freedom and respective areas. Across these series the observed values are the same, but the missing values are filled in with different imputations to reflect uncertainty levels. Then, for estimations over the period 19752015, we regress the model five times using the five series. The estimates reported for each coefficient are the average of the five separate estimates; the respective standard error is obtained by computing the square root of the average of the estimated variances from each individual estimate plus the sample variance in the point estimates across the five estimates, multiplied by a factor that corrects for the bias. For further details, see King et al. (2001, p.53).

${ }^{11}$ A similar specification is employed in the estimations for the five areas of economic freedom, where EconFreedom is successively replaced by GovSize, LegalSystem, SoundMoney, FreedomTrade, and Regulation.
} 
like global shocks, institutional and socio-economic changes or technological progress no accounted for in our set of variables; ${ }^{12}$ finally, $\varepsilon_{i t}$ is the usual error term.

Given the presence of individual effects, $\alpha_{i}$, the model can be estimated assuming those effects as fixed or random. However, the lagged value of the dependent variable would be correlated with the error term even if the latter is not serially correlated. This implies that OLS estimates (random or fixed effects) will be biased and inconsistent (Baltagi, 2013). The estimators that take into account that bias can be grouped into: (i) bias-corrected estimators, best suited when the number of individuals $(N)$ is small and the number of time periods $(T)$ is not very large; and (ii) instrumental variables estimators, more adequate when there is a clear dominance of cross sections $(N)$ over time periods $(T)$ and with the additional feature of tackling the potential endogeneity of other variables by using internal instruments. In our panel structure, although $T$ is not large (in particular, when we use the sample 2000-2015), the number of individuals cannot be considered small $(N=106)$. As such, we resort to the class of estimators known as GMM (generalized method of moments) estimators, first proposed by Arellano and Bond (1991) to solve the bias problem, thus allowing for a more consistent and efficient way of estimating dynamic models. While the GMM approach yields consistent estimators, the original difference-GMM estimators developed by Holtz-Eakin et al. (1988) and Arellano and Bond (1991) may suffer from finite sample biases. These biases arise particularly when time series are persistent. Arellano and Bover (1995) and Blundell and Bond (1998) recommend additional moment conditions, since - as long as they are valid - they increase the efficiency of the estimators. This estimator is known as the system-GMM estimator and allows

\footnotetext{
12 Given the relatively high number of time periods (and to avoid the proliferation of instruments in the estimator we employ in the empirical analysis), these time effects are captured by including a trend in the specification.
} 
for higher accuracy and reduced finite sample bias (Bond, 2002; Baltagi, 2013). ${ }^{13}$ Our model is estimated by system-GMM with a two-step approach. To avoid over-fitting biases, instruments are collapsed as suggested by Roodman (2009a, b). Moreover, equally to avoid the proliferation of instruments, we treat only the lag of the dependent variable (EconFreedom or its areas) and Democracy as endogenous; as for other potential endogenous variables, like GDPpc, Trade and Education, we use their five-year averages - instead of simply their lagged values - to mitigate the problem of reverse causality and treat them as exogenous. ${ }^{14}$

\section{Empirical Analysis}

This section starts with the discussion of the general results from the estimation of the model to the period 2000-2015. Then we move to a closer analysis of the ideological effects and broad areas of economic freedom. Finally, relying on the imputation techniques described above, the analysis is extended to the period $1975-2015$.

\subsection{Initial findings}

Table 2 reports the results from the system-GMM estimations for the economic freedom specification over the period 2000-2015. Two-step results using robust standard errors corrected for finite samples (Windmeijer, 2005) are reported in parenthesis and the respective significance level is indicated with asterisks. The number of observations, countries, instruments, $p$-values for the

\footnotetext{
${ }^{13}$ For this to be valid, the system-GMM requires the stationarity of the variables and the lack of correlation between the first differences of the instruments and the specific effects (Baltagi, 2013). ADF Fisher-type panel unit root tests were performed for the dependent and independent variables used in this study. The results are presented in Annex (see Table A.3) and show that the null hypothesis that all panels contain unit roots is rejected for all the variables that we use in our regressions.

${ }^{14}$ The lag of EconFreedom and Democracy are instrumented with their lags in the first-difference and level equations while the exogenous variables are instrumented with their own values.
} 
serial correlation, Hansen, and Difference-in-Hansen tests are reported at the bottom of the Table 2. These tests support the dynamic specification employed and the validity of the instruments used.

\section{[INSERT TABLE 2 AROUND HERE]}

The results are clear and robust in showing that economic freedom, over the period 20002015, is significantly higher when right-wing parties are in office relative to other governments (centre and left- or simply left-wing governments - see columns 1 and 2). Looking at the results in the baseline specification in column 1, we observe that the Economic Freedom index is on average around 0.05 points higher with right-wing governments, ceteris paribus. This is the short-run effect; in the long run, the impact is higher: $0.28(=0.05 /(1-0.82))$. This means that right-wing governments contribute to a 0.28 points increase in economic freedom in the long-run. Hence, when in office, those parties do what they are expected to do in terms of promoting economic freedom. This finding is in line with the results found by Pitlik (2007), Potrafke (2013) and Jager (2017). On the contrary, no statistically relevant effect is found when left-wing parties are in office (see column 3).

Regarding the political and socioeconomic controllers, we find no significant effect on economic freedom from Election, MajGov or even TimeOffice. As to the quality of democracy (Democracy), there is some weak evidence that better democracy is positively associated with higher economic freedom, as some studies suggest (see footnote 7). ${ }^{15}$ In regression 2, we add the dummy Centre to the model, but its coefficient is statistically insignificant, so we can keep it in the base category with Left. In regression 4, we interact Right with MajGov to assess whether right-wing governments with majority are more prone to promote more economic freedom, but the differences in political support are found to be irrelevant. Most likely coalition governments lead by right parties

\footnotetext{
15 We also considered the machine learning democracy index proposed by Gründler and Krieger (2016) as an alternative proxy for the quality of democracy. Despite the number of observations being reduced in that experiment, the findings were quite similar. Those results are not reported here to save space, but they are available upon request.
} 
are, in most cases, formed with other right-wing parties. A similar conclusion is reached when TimeOffice is interacted with Right (column 5). Time in office does not seem to undermine the intensification of economic freedom undertaken by right-wing governments. However, we observe that after a regime change, the level of economic freedom increases significantly during the first term in office of a right-wing government $($ RightTerm $=1)$ - see column 6 - with the magnitude and significance of the effect decreasing slightly thereafter (RightTerm $>1)$. Nevertheless, the important positive impact of right-wing governments on economic freedom does not fade away and remains relevant throughout all its time in office, which is in line with what we observe in regression 5.

Focusing now on the socio-economic factors, the logarithm of the five-year average of real GDP per capita $(L n G D P p c)$ was the only variable that proved not to have a statistically significant coefficient. ${ }^{16}$ As expected, more openness to trade, absence of financial crises and more educated population are beneficial for economic freedom.

\subsection{Closer analysis of the ideological effects}

This section analyses two important aspects regarding the effect of ideology. On the one hand, it investigates potential differences between the groups of developed and developing/emerging countries. On the other hand, it refines the traditional, but simplistic, right-left divide for government orientation. This more detailed analysis addresses the concern that the world is not just "right", "left" or "centre", by accounting for some important nuances observed in real-world politics. We examine two particular aspects. The first is whether a government is fully constituted by right (left) parties

\footnotetext{
${ }^{16}$ This variable is obtained from the averaged of the previous five years. We use the logarithm to compress the scale of measure; this also allows the interpretation of the results in terms of semi-elasticity. We have also tried the lagged log of real GDP per capita and the lagged values (and five-year averages) of real GDP growth but none resulted in a statistically significant coefficient for these variables (the other results remained qualitatively and quantitatively unchanged). Those results are not reported here to save space, but they are available upon request.
} 
or if the dominant right (left) ruling party simply leads a coalition with others from different quadrants. Hegemonic governments are expected to be in better conditions to execute their agendas. The second aspect tackles a growing phenomenon in modern democracies: the emergence of populist governments. Relying on Kyle and Gultchin's (2018) identification of populists in office, we create the dummies PopRight and PopLeft identifying right and left populist governments, respectively. The other governments are considered to be established right-wing (EstabRight) or left-wing (EstabLeft) governments.

Populism is a loose label that comprises a variety of movements with specific motivations and agendas (Gidron and Bonikowski 2013). The political evolution of the last decades has made the classification of parties in the left-right spectrum increasingly difficult. The emergence and success of populism reinforces the notion that parties and voters exhibit multidimensional political attitudes and preferences. Laméris et. al. (2018) validate four relevant dimensions: economic equality; markets and efficiency; personal and cultural freedom; and nationalist, protectionist and populist preferences. Labeling populist parties as left- or right-wing is admissible, however it is more subjective than placing traditional parties. For instance, when it comes to maintaining the welfare state, several populist parties, that are right-wing in other respects, are against reforms like left-wing parties. Moreover, some populist right-wing parties can be pro-market but defend some degree of economic protectionism. Hence, when using the left-right divide in the case of populist parties, we must be aware of the particularities that arise from this classification. Nevertheless, populist governments generally share a strong resistance to foreign influence and tend to exert more control over the society. As such, it is admissible to find left-wing populist governments more proactive in reducing economic freedom than their more moderate counterparts. The expected effect of right-wing populist governments is less clear. The traditional right-wing tendency towards free 
markets can clash with the resistance to outside influences and with the "us versus them" speech these parties usually have. Hence, we expect them to provide a smaller boost to economic freedom than mainstream right-wing governments. How much smaller or whether there is a detrimental effect are questions best answered empirically.

The results of this empirical analysis are reported in columns 1 and 2 in Table $3 .{ }^{17}$ They show that economic freedom increases substantially with established (or non-populist) right-wing governments. However, no distinctive effect can be attributed to the populist right (see column 1). Overall, we can conclude that right-wing governments - especially mainstream ones - promote more economic freedom than any other type of government.

On the contrary, while economic freedom is not significantly affected by well-established left-wing governments (EstabLeft), populist ones (PopLeft) undermine economic freedom significantly (see column 2). Even though the overall negative effect of Left (see column 3 in Table 2) is not significant, when we separate the mainstream left from the populist one, we find that economic freedom decreases by about 0.09 points when the latter are in office.

\section{[INSERT TABLE 3 AROUND HERE]}

Regarding the potential differences between hegemonic and non-hegemonic governments we constructed four dummies, relying on the GOV_PARTY variable provided by the CPDS database: hegemony of right parties (HegRight); dominance of right parties (DomRight); hegemony of left parties (HegLeft); and dominance of left parties (DomLeft). Those are included in regressions 3 and 4, which show that economic freedom benefits more from governments with hegemony of right-wing parties, while it is mainly undermined when left-wing parties in office are dominant but

\footnotetext{
17 The estimations reported in Table 3 include the same set of political and socio-economic controllers used in the regressions reported in Table 2. The results for those controllers have proven to be very similar as well as the results of the GMM tests. They are not reported here to save space, but they are available upon request.
} 
not hegemonic. ${ }^{18}$ We conjecture that the emergence of this unexpected effect for the left may relate to the possibility that mainstream left governments tend to ally themselves with extreme left parties, typically more prone to implement ideological based policies. Again, despite accounting for alternative "shades of right and left", we end up concluding that right-wing governments do more for economic freedom than any other party. ${ }^{19}$

The second part of Table 3 (columns 5-6) assesses any potential differences between the groups of developed and developing/emerging countries using the DPI dataset again. In column 5, the model is extended with the inclusion of a dummy for OECD and its interaction term with Right. There is some evidence that, on average, economic freedom is higher in the subgroup of OECD countries. However, no significant ideological effects are found with this divide.

In regression 6, we use Mousseau's (2012) Contract Intensive Economy (CIE) index as an alternative measure of development. The CIE ranges from 0.12 and 8.74 and measures the level of development of countries, in the sense that those more market-developed tend to be more contractintensive, i.e. where most citizens regularly obtain goods and services contracting with strangers located in a market. The results show that countries with a higher level of contract-intensity (i.e. more developed markets) tend to exhibit a higher level of economic freedom, but this effect tends to be significantly dampened in these same markets when right-wing parties are in office. This suggests that the effect of government ideology (Right) is stronger in developing/emerging countries

\footnotetext{
${ }^{18}$ Even though the government orientation effect remains similar to the one obtained with political data from the DPI database, the sample used here is different: the CPDS database comprises only 34 developed countries. For that same reason, the estimator used in regressions 3 and 4 is different. As the number of individuals is low and the number of time periods is not large, Bruno's (2005a, b) LSDVC estimator for dynamic panel data models is more adequate to deal with this panel structure. The Blundell-Bond procedure is used as the initial estimator in the LSDVC estimations; 100 repetitions of the procedure to bootstrap the estimated standard errors were undertaken.

${ }^{19}$ Note that the some of the estimated coefficients for HegRight and DomRight is positive and statistically significant. A similar conclusion is reached if we use a simple dummy for Right (HegRight+DomRight) in the model. The results are not reported here but they are available upon request.
} 
than in more developed ones. ${ }^{20}$ This result can somehow be linked to the convergence hypothesis: the theory predicts faster growth for economies that have not reached their steady-state value yet (Solow, 1956; Barro, 1991; Sala-i-Martin, 1996). This might be what is happening here as governments in developing/emerging countries have more margin to improve economic freedom than in more developed markets (where higher levels have already been reached). In fact, over the period 2000-2015 the average of the Economic Freedom index was 7.5 in the group of more developed OECD countries and 6.5 in the developing/emerging economies.

\subsection{The effect of right-wing governments on the main areas of economic freedom}

The results found so far establish a robust link between right governments and economic freedom. Now it is important to assess which areas of economic freedom are improved under their ruling. Table 4 presents results for the five areas of economic freedom over the period 2000-2015.

\section{[INSERT TABLE 4 AROUND HERE]}

Looking at the estimated coefficients on the dummy Right across all the regressions, it seems that right-wing governments do not tend to promote economic freedom in all five categories. In areas such as the size of government and the legal framework they do not behave differently from other parties. However, right-wing governments improve monetary soundness and price stability. In fact, according to the partisan business cycles literature (Hibbs, 1977; Alesina, 1987; Alesina and Sachs, 1988) they are more concerned with inflation than left-wing governments. Therefore, their efforts to promote price stability end up intensifying economic freedom in the area of sound money. Additionally, our results also show them as more prone to boost freedom to trade internationally and to ease regulations that restrict entry into markets or limit the freedom of exchange in credit, labor,

\footnotetext{
${ }^{20}$ Nevertheless, this result should be analysed with some care as the estimations are limited to the period 2000-2012 when CIE is included in the model.
} 
or product markets. In particular, this evidence for Regulation corroborates the claim in the literature that right-wing governments are more prone to deregulate the economy (Potrafke, 2010; Bjørnskov and Potrafke, 2012, 2013; Aidt et al., 2018). ${ }^{21}$

Regarding the political and socio-economic controllers, a better democratic environment helps to boost the role of the legal system and rule of law; the results for output per capita are mixed: higher levels of income per capita reduce economic freedom in the area of government size, maybe because government size is positively related to GDP per capita; but higher real GDPpc tend to be linked to the promotion of the rule of law and consequently more freedom in this area. Trade openness and education exhibit a similar result, but both are also positively associated with more freedom to trade internationally and regulation. Finally, financial crises have proved to be a very harmful event for all areas of economic freedom.

\subsection{Imputation approach}

The above results hold for the period 2000-2015, for which the Fraser Institute provides annual data. In this section, we extend the analysis to the period 1975-2015. To generate the missing data for the period 1970-2000, we employ King et al. (2001) multiple imputation method. ${ }^{22}$ Tables $^{2}$ 5 and 6 report, respectively, the results for the Economic Freedom index and for the respective broad areas. Overall, they confirm our previous findings but there are a few specificities in this analysis that is worth to notice. First, with the exception of regressions 2 and 4 in Table 5, the estimated coefficients are the averages of the coefficients obtained from five imputations of the index and the

\footnotetext{
${ }^{21}$ Similar regressions were conducted replacing the dummy Right by a dummy for left-wing governments, however this variable was found to be statistically insignificant across all five categories. To keep the analysis parsimonious, those results are not reported here but they are available upon request.

22 Note that we end up using data for the period 1975-2015 because DPI only reports political data from 1975 onwards.
} 
standard errors are obtained following King et al. (2001). ${ }^{23}$ Regressions 2 and 4 retrieve estimates where the average of the five imputed series is used as dependent variable. Whether we use King et al. (2001) approach to compute the estimates or the average of the five EconFreedom imputed series as dependent variable, the results remain essentially the same (compare columns 1-2 and 3-4).

We started by estimating our baseline model with education in the list of regressors. However, since data for this variable are restricted to the period 1990-2015 (with some missing values for some countries), the number of observations is only slightly higher than when we rely on the 2000-2015 period. Hence, this does not add much to the previous analysis, confirming the importance of education for economic freedom. For the sake of increasing the time span, we removed Education from the list of regressors in the subsequent estimations (see regressions 3 and 4, in particular). The results for the other variables do not vary much, with the exception of $L n G D P p c$ and Trend. The first becomes relevant and uncovers the importance of real GDP per capita to promote economic freedom; the coefficient on the trend variable also becomes highly significant, which, in part, might be collecting the effect that increasing education levels might have had over time on improving economic freedom.

\section{[INSERT TABLE 5 AROUND HERE]}

Most importantly, with or without education, with or without imputation, the results reinforce the idea that right-wing governments are more prone to increase economic freedom than centre or left-wing ones (even when data from CPDS database is used instead - see column 6). ${ }^{24}$

\footnotetext{
${ }^{23}$ We follow King et al. (2001, p.53) to compute the coefficients and standard errors; the $p$-values presented at the bottom of Tables 5 and 6 are also obtained as the average of the $p$-values from the individual estimations where each of the five imputed series is used. These provide a gross approximation of the true $p$-values. In fact, they are not very different from the cases where average of the imputed series is used instead as dependent variable (regressions 2 and 4 ). ${ }^{24}$ Note that the estimator used in regression 6 is different. As the number of individuals is low and the number of time periods is large (41 years), the FE estimator becomes adequate: it converges as $T$ increases. The dummy Right, in this particular case, corresponds to the sum of the dummies HegRight and DomRight (as described above). Additional
} 
This suggests that partisan effects over economic freedom seem to exist not just in this century but also when we add the final three decades of the $20^{\text {th }}$ century, revealing the significant temporal consistency of the phenomenon.

Looking at the estimations for the five broad areas presented in Table 6, results are well in line with those reported in Table 4 and discussed above in sub-section 4.3. Now real GDP per capita gains some (positive) relevance in other areas of economic freedom, but without compromising the importance of political orientation for SoundMoney, FreedomTrade and Regulation.

\section{[INSERT TABLE 6 AROUND HERE]}

As a final exercise - and to overcome the limitations of multiple imputation techniques in generating values for the missing observations - the baseline model was estimated using five-year time spans and legislative term spans over the period 1975-2015. Although there is a significant loss of information (available in annual data), the results using a two-step system GMM estimator corroborate our previous findings, as can be observed in Table A.4 and A.5 reported in Annex (EconFreedom: columns 1-3; respective areas: columns 4-8). ${ }^{25}$

\section{Concluding remarks}

This study provides a clearer picture on the role of ideology in shaping the economic environment by putting to the test the rooted conception that right-wing governments tend to steer a society into a free market economy while left governments navigate in the opposite direction. For this purpose, we use annual data for 106 countries over the period 1975-2015 and the Economic

estimations with the FE estimator were also performed with the entire sample of 106 countries but the main conclusions remained essentially unchanged. Those results are not reported here but they are available upon request.

${ }^{25}$ As in the estimations above, LnGDPpc, Trade and Education are averages over the previous 5 years spans (Table A.4) or legislative period (Table A.5). Now FinCrisis corresponds to the fraction of time a country is in crisis over the previous five years (A.4) or legislative period (A.5). Democracy is instrumented with either its five-year average (A.4) or legislative period (A.5) average. The other political variables correspond to their contemporaneous values as before. 
Freedom index computed by Fraser Institute. A two-step system GMM estimator is employed and several samples are tested. To better understand where exactly ideology is relevant in shaping the economic environment, we also take a closer look at the five major areas of economic freedom.

Overall, the results strongly suggest that ideology affects the background in which economic agents operate, stressing the idea that when voters are deciding between electing a right- or a leftwing government, they are deciding - among other things - whether they want more or less economic freedom. We found that right-wing parties, when in office, actually do what they are expected to do: they promote economic freedom. The reported effect is almost twice as strong in developing/emerging economies than in more developed countries. However, left-wing governments do not seem to undermine economic freedom as expected by voters and political theorists, except when the populist left is in office. In these cases, economic freedom is substantially reduced during their tenure. The results provided in this paper are robust to the time period considered, estimation procedure and across different areas of economic freedom. Also, partisan effects seem to exist not just in this century but also when we add the final three decades of the $20^{\text {th }}$ century, through data imputation techniques, revealing that the phenomenon has a significant temporal consistency.

However, not all areas of economic freedom are found to exhibit partisan effects. The size of government and the legal framework seem to be unaffected by the incumbent's ideology. Right wing parties tend to promote economic freedom by easing regulations that restrict entry into markets or limit the freedom of exchange in credit, labor, or product markets, thus encouraging a laissez fair laissez passer environment in the economy. They also increase monetary soundness, promoting price stability and low inflation, a trait consensually attributed to right parties. Results also show 
that they are more prone to boost freedom to trade internationally, being capable to deliver better conditions for their residents to engage in voluntary exchanges with people in other countries.

Other potentially relevant political aspects such as the time spent in office and majority governments do not seem to be important for the explanation of economic freedom, even when we restrict their effects to periods when the right is in power. Yet, right-wing governments seem to have a stronger positive effect on economic freedom in their first term in office.

Finally, other factors like the quality of democracy, level of income per capita, trade openness, financial crises and the level of education have also proved to be important to explain the changes in the level of the Economic Freedom index over the last decades. 


\section{References}

Aidt, T., Castro, V., Martins, R., 2018. Shades of red and blue: Government ideology and sustainable development. Public Choice 175, 303-323.

Aixalá, J., Fabro, G., 2009. Economic freedom, civil liberties, political rights and growth: A causality analysis. Spanish Economic Review 11(3), 165-178.

Alesina, A., 1987. Macroeconomic policy in a two-party system as a repeated game. Quarterly Journal of Economics 1023, 651-678.

Alesina, A., Sachs, J., 1988. Political parties and business cycle in the United States, 1948-84. Journal of Money, Credit and Banking 201, 63-82.

Alesina, A., Cohen, G., Roubini, N., 1997. Political cycles and the macroeconomy. The MIT Press, Cambridge.

Alesina, A., Ardagna, S., Trebbi, F., 2006. Who Adjusts and When? On the Political Economy of Stabilisations. IMF Staff Papers, 53.

Apergis, N., Dincer, O., Payne, J., 2014. Economic Freedom and Income Inequality Revisited: Evidence from a Panel Error Correction Model. Contemporary Economic Policy 32(1), 6775.

Arellano, M., Bond, S., 1991. Some Tests of Specification for Panel Data: Monte Carlo Evidence and an Application to Employment Equations. Review of Economic Studies 58, 277-297.

Arellano, M., Bover, S., 1995. Another look at the instrumental variable estimation of error components models. Journal of Econometrics 68(1), 29-51.

Armingeon, K., Wenger, V., Wiedemeier, F., Isler, C., Knöpfel, L., Weisstanner, D., Engler, S., 2017. Comparative Political Data Set 1960-2015. Institute of Political Science, University of Berne: http://www.cpds-data.org/.

Baltagi, B., 2013. Econometric Analysis of Panel Data, 5th Ed. John Wiley \& Sons, Ltd, Chichester, UK.

Barro, R., 1991. Economic growth in a cross section of countries. Quarterly Journal of Economics 106, 407-501.

Bjørnskov, C., Potrafke, N., 2012. Political ideology and economic freedom across Canadian provinces. Eastern Economic Journal 38, 143-166.

Bjørnskov, C., Potrafke, N., 2013. The size and scope of government in the US states: Does party 
ideology matter? International Tax and Public Finance 20, 687-714.

Blundell R., Bond, S., 1998. Initial conditions and moment restrictions in dynamic panel data models. Journal of Econometrics 87(1), 115-143.

Bond, S., 2002. Dynamic panel data models: A guide to micro data methods and practice. Portuguese Economic Journal 1, 141-162.

Botero, J. C., Djankov, S., La Porta, R., Lopez-de-Silanes, F., Shleifer, A. 2004. The regulation of labor. The Quarterly Journal of Economics 119(4), 1339-1382.

Bruno, G., 2005a. Estimation and inference in dynamic unbalanced panel-data models with a small number of individuals. Stata Journal 5(4), 473-500.

Bruno, G., 2005b. Approximating the bias of the LSDV estimator for dynamic unbalanced panel data models. Economics Letters 87(3), 361-366.

Caplan, B., 2001. What makes people think more like economists? Evidence from economic cognition from the Survey of Americans and Economists on the Economy. Journal of Law and Economics 44(2), 395-426.

Caplan, B., Miller, S., 2010. Intelligence makes people think more like economists: Evidence from the General Social Survey. Intelligence 38(6), 636-647.

Crowley, G., Dove, J., Sutter D., 2017. Voter preferences, institutions, and economic freedom. Contemporary Economic Policy 35(1), 76-92.

Cruz, C., Keefer, P., Scartascini, C., 2016. Database of Political Institutions Codebook; 2015 update (DPI2015). Inter-American Development Bank. Updated version of Thorsten Beck, George Clarke, Alberto Groff, Philip Keefer, and Patrick Walsh, 2001. New tools in comparative political economy: The Database of Political Institutions." 15:1, 165-176 (September), World Bank Economic Review.

de Haan, J., Lundström, S., Sturm, J-E, 2006. Market-oriented institutions and policies and economic growth: A critical survey. Journal of Economic Surveys 20(2), 157-191.

de Haan, J., Sturm, J.-E., 2003. Does more democracy lead to greater economic freedom? New evidence for developing countries. European Journal of Political Economy 19(3), 547-563.

de Haan, J., Sturm, J.-E., Zandberg, E., 2009. The impact of financial and economic crises on economic freedom. Economic freedom of the World: 2009 Annual report. Fraser Institute, Vancouver.

de Haan, J., Sturm, J-E., 2000. On the Relationship Between Economic Freedom and Economic 
Growth. European Journal of Political Economy 16 (2), 215-41.

de Haan, J., Sturm, J-E., 2001. How Robust Is the Relationship Between Economic Freedom and Economic Growth? Applied Economics 33(7), 839-44.

de Haan, J., Parlevliet, J. (Eds.), 2018. Structural Reforms. Springer International Publishing.

Drazen, A., Easterly, W., 2001. Do crises induce reform? Simple empirical tests of conventional wisdom. Economic and Politics 13, 129-157.

Dreher, A., 2006. Does Globalization Affect Growth? Evidence from a new Index of Globalization, Applied Economics 38 (10), 1091-1110.

Farr, W. K., Lord, R. A., Wolfenbarger, J. L., 1998. Economic freedom, political freedom, and economic well-being: a causality analysis. Cato Journal 18(2), 247-262.

Franzese, R., 2002. Electoral and Partisan cycles in economic policies and outcomes. Annual Review of Political Science 5, 369-421.

Gidron, N., Bonikowski, B., 2013. Varieties of populism: Literature review and research agenda, Weatherhead Working Paper Series, No. 13-0004, Harvard University.

Gründler, K., Krieger, T., 2016. Democracy and growth: Evidence from a machine learning indicator. European Journal of Political Economy 45, 85-107.

Gwartney, J. G., Lawson, R. A., 2002. Economic Freedom of the World: 2002 Annual Report. Fraser Institute, Vancouver.

Gwartney, J., Lawson, R., Hall, J., 2017. Economic Freedom of the World: 2017 Annual Report. Fraser Institute, Vancouver: https://www.fraserinstitute.org/studies/economic-freedom.

Gygli, S., Haelg, F., Potrafke, N., Sturm, J.E., 2019. The KOF Globalisation Index - Revisited Review of International Organizations 14(3), 543-574.

Hankins, W. B., Hoover, G. A., 2019. Do Democratic governors lower economic freedom? A regression discontinuity approach. Journal of Public Finance and Public Choice 34(2), 101126

Hibbs, D. A., 1977. Political parties and macroeconomic policy. American Political Science Review $71,1467-1487$.

Holtz-Eakin, D., Newey, W., Rosen, H., 1988. Estimating vector autoregressions with panel data. Econometrica 56, 1371-1395.

Islam, Md. R., 2018. Wealth inequality, democracy and economic freedom. Journal of Comparative Economics 46(4), 920-935. 
Jäger, K., 2017. Economic Freedom in the Early 21st Century: Government Ideology Still Matters. Kyklos 70(2), 256-277

King, G., Honaker, J., Joseph, A., Scheve, K., 2001. Analyzing Incomplete Political Science Data: An Alternative Algorithm for Multiple Imputation. American Political Science Review 95, 49-69.

Krieger, T., Meierrieks, D., 2016. Political capitalism: The interaction between income inequality, economic freedom and democracy. European Journal of Political Economy 45, 115-132.

Kyle, J., Gultchin, L., 2018. Populists in Power Around the World. Tony Blair Institute for Global Change: http://institute.global/insight/renewing-centre/populists-power-around-world

Laeven, L., Valencia, F., 2018. Systemic banking crises revisited. IMF Working Paper, WP/18/206.

Laméris, M., Jong-A-Pin, R., Garretsen, H., 2018. On the measurement of voter ideology. European Journal of Political Economy 55, 417-432.

Lipford, J., Yandle, B., 2015. Determining economic freedom: Democracy, political competition, and the wealth preservation struggle. Journal of Private Enterprise 30(3), 1-18.

Lundström, S., 2005. The effect of democracy on different categories of economic freedom. European Journal of Political Economy 21(4), 967-980.

Marshall, M., Gurr, T., Keith, J., 2017. Polity IV Project: Political Regime Characteristics and Transitions, 1800-2016. Center for Systemic Peace: www.systemicpeace.org.

Mousseau, M., 2012. Capitalist Development and Civil War. International Studies Quarterly 56, 470-483.

Murphy, R. H., Smith, T. L., 2017. Aggregate demand shortfalls and economic freedom. Review of Austrian Economics 31(1), 111-122.

Murphy, R. H., 2019. The long-run effect of government ideology on economic freedom, Economic Affairs 39, 101-114.

Nguyen, T. C., Castro, V., Wood, J., 2020. Political environment and financial crises. International Journal of Finance and Economics, forthcoming.

Pitlik, H., Wirth, S., 2003. Do crises promote the extent of economic liberalization? An empirical test. European Journal of Political Economy 19, 565-581.

Pitlik H., 2007. A race to liberalization? Diffusion of economic policy reform among OECDeconomies. Public Choice 132(1) 159-178.

Potrafke, N., 2010. Does government ideology influence deregulation of product markets? 
Empirical evidence from OECD countries. Public Choice 143(1-2), 135-155.

Potrafke, N., 2013. Economic Freedom and Government Ideology across the German States. Regional studies 47(3), 433-449.

Potrafke, N., 2017. Partisan politics: The empirical evidence from OECD panel data studies. Journal of Comparative Economics 45(4), 712-750.

Rodrik, D. 1996. Understanding economic policy reform. Journal of Economic Literature 34, 9-41.

Roodman, D. M., 2009a. How to do xtabond2: An introduction to difference and system GMM in Stata. Stata Journal 9(1), 86-136.

Roodman, D. M., 2009b. A note on the theme of too many instruments. Oxford Bulletin of Economics and Statistics 71, 135-158.

Sala-i-Martin, X., 1996. Regional cohesion: Evidence and theories of regional growth and convergence. European Economic Review 40, 1325-1352.

Solow, R., 1956. A contribution to the theory of economic growth. Quarterly Journal of Economics 70(1), 65-94.

Stocker, M. L., 2016. Crisis facilitates policy change not liberalization. Journal of Financial Economic Policy 8(2), 248-267.

UNDP, 2016. Human Development Report 2016. United Nations Development Programme: http://hdr.undp.org.

Vega-Gordillo, M., Álvarez-Arce, J., 2003. Economic growth and freedom: A causality study. Cato Journal 23(2), 199-215.

Ward, H., Ezrow, L., Dorussen, H., 2011. Globalization, Party Positions, and the Median Voter. World Politics 63(3), 509-547.

Windmeijer, F., 2005. A finite sample correction for the variance of linear efficient two-step GMM estimators. Journal of Econometrics 126(1), 25-51. 


\section{TABLES}

Table 1. Description of the variables and descriptive statistics

\begin{tabular}{|c|c|c|c|c|c|c|}
\hline Variable & Description & Obs. & Mean & S.D. & Min. & Max \\
\hline EconFreedom & $\begin{array}{l}\text { Economic Freedom index; it measures the degree } \\
\text { to which the policies and institutions of countries } \\
\text { are supportive of economic freedom; it is also } \\
\text { disaggregated into five broad areas: }\end{array}$ & $\begin{array}{c}1652 \\
{[2816]}\end{array}$ & $\begin{array}{c}6.81 \\
{[6.62]}\end{array}$ & $\begin{array}{c}0.91 \\
{[0.95]}\end{array}$ & $\begin{array}{c}2.92 \\
{[1.60]}\end{array}$ & $\begin{array}{c}8.86 \\
{[9.05]}\end{array}$ \\
\hline SizeGov & Size of government & 1652 [2816] & $6.39[6.06]$ & $1.32[1.36]$ & $2.36[0.64]$ & $9.49[10.0]$ \\
\hline LegalSystem & Legal system and property rights & 1652 [2816] & 5.40 [5.52] & $1.71[1.62]$ & $2.01[0.99]$ & 9.14 [9.14] \\
\hline SoundMoney & Sound money & $1652[2816]$ & $8.15[7.83]$ & $1.54[1.56]$ & $0.00[0.00]$ & $9.89[9.89]$ \\
\hline FreedomTrade & Freedom to trade internationally & $1652[2816]$ & $7.25[7.03]$ & $1.10[1.24]$ & $2.06[0.00]$ & $9.49[10.0]$ \\
\hline Regulation & Regulation & 1652 [2816] & 6.86 [6.72] & $0.98[0.98]$ & $2.36[1.61]$ & $9.12[9.12]$ \\
\hline Right & $\begin{array}{l}\text { Dummy variable that takes de value of } 1 \text { when a } \\
\text { right-wing party is in office; and } 0 \text {, otherwise. }\end{array}$ & $\begin{array}{c}1678 \\
{[3426]}\end{array}$ & $\begin{array}{c}0.26 \\
{[0.31]}\end{array}$ & $\begin{array}{c}0.44 \\
{[0.46]}\end{array}$ & $\begin{array}{c}0 \\
{[0]}\end{array}$ & $\begin{array}{c}1 \\
{[1]}\end{array}$ \\
\hline Centre & $\begin{array}{l}\text { Dummy variable that takes de value of } 1 \text { when a } \\
\text { centre-wing party is in office; and } 0 \text {, otherwise. }\end{array}$ & $\begin{array}{l}1678 \\
{[3426]}\end{array}$ & $\begin{array}{c}0.08 \\
{[0.09]}\end{array}$ & $\begin{array}{c}0.27 \\
{[0.29]}\end{array}$ & $\begin{array}{c}0 \\
{[0]}\end{array}$ & $\begin{array}{c}1 \\
{[1]}\end{array}$ \\
\hline Election & $\begin{array}{l}\text { Dummy variable that takes de value of } 1 \text { in the } \\
\text { year of legislative elections; and } 0 \text {, otherwise. }\end{array}$ & $\begin{array}{c}1684 \\
{[3458]}\end{array}$ & $\begin{array}{c}0.25 \\
{[0.24]}\end{array}$ & $\begin{array}{c}0.43 \\
{[0.43]}\end{array}$ & $\begin{array}{c}0 \\
{[0]}\end{array}$ & $\begin{array}{c}1 \\
{[1]}\end{array}$ \\
\hline MajGov & $\begin{array}{l}\text { Dummy variable that takes de value of } 1 \text { when } \\
\text { the party in office has a majority in the } \\
\text { parliament; and } 0 \text {, otherwise. }\end{array}$ & $\begin{array}{c}1667 \\
{[3369]}\end{array}$ & $\begin{array}{c}0.77 \\
{[0.78]}\end{array}$ & $\begin{array}{l}0.42 \\
0.41\end{array}$ & $\begin{array}{c}0 \\
{[0]}\end{array}$ & $\begin{array}{c}1 \\
{[1]}\end{array}$ \\
\hline TimeOffice & Number of years a party is in office. & $\begin{array}{c}1527 \\
{[3161]}\end{array}$ & $\begin{array}{c}9.16 \\
{[9.25]}\end{array}$ & $\begin{array}{l}10.54 \\
10.92\end{array}$ & $\begin{array}{c}1 \\
{[1]}\end{array}$ & $\begin{array}{c}71 \\
{[71]}\end{array}$ \\
\hline Democracy & $\begin{array}{l}\text { Autocracy-Democracy index for quality of } \\
\text { democracy; it describes how democratic a } \\
\text { country is in a scale ranging from }-10 \text { (strongly } \\
\text { autocratic) to }+10 \text { (strongly democratic). }\end{array}$ & $\begin{array}{c}1669 \\
{[3436]}\end{array}$ & $\begin{array}{c}6.56 \\
{[6.06]}\end{array}$ & $\begin{array}{c}4.27 \\
{[5.05]}\end{array}$ & $\begin{array}{c}-7 \\
{[-9]}\end{array}$ & $\begin{array}{c}10 \\
{[10]}\end{array}$ \\
\hline$G D P p c$ & $\begin{array}{l}\text { Real gross domestic product per capita (base } \\
\text { year: 2010; US\$). }\end{array}$ & $\begin{array}{c}1683 \\
{[3462]}\end{array}$ & $\begin{array}{c}15172 \\
{[14194]}\end{array}$ & $\begin{array}{c}20166 \\
{[17922]}\end{array}$ & $\begin{array}{c}219.19 \\
{[170.58]}\end{array}$ & $\begin{array}{c}111968 \\
{[111968]}\end{array}$ \\
\hline Trade & $\begin{array}{l}\text { Trade openness: exports plus imports as a } \\
\text { percentage of GDP. }\end{array}$ & $\begin{array}{c}1681 \\
{[3431]}\end{array}$ & $\begin{array}{l}85.25 \\
{[77.26]}\end{array}$ & $\begin{array}{c}51.17 \\
{[50.27]}\end{array}$ & $\begin{array}{l}19.80 \\
{[9.10]}\end{array}$ & $\begin{array}{c}441.60 \\
{[441.60]}\end{array}$ \\
\hline FinCrisis & $\begin{array}{l}\text { Dummy variable that takes de value of } 1 \text { when a } \\
\text { financial crisis is occurring; and } 0 \text {, otherwise. }\end{array}$ & $\begin{array}{l}1685 \\
{[3566]}\end{array}$ & $\begin{array}{c}0.30 \\
{[0.33]}\end{array}$ & $\begin{array}{c}0.46 \\
{[0.47]}\end{array}$ & $\begin{array}{c}0 \\
{[0]}\end{array}$ & $\begin{array}{c}1 \\
{[1]}\end{array}$ \\
\hline Education & $\begin{array}{l}\text { Education index computed using mean years of } \\
\text { schooling and expected years of schooling. }\end{array}$ & $\begin{array}{c}1672 \\
{[2585]}\end{array}$ & $\begin{array}{c}0.64 \\
{[0.61]}\end{array}$ & $\begin{array}{c}0.18 \\
{[0.18]}\end{array}$ & $\begin{array}{c}0.12 \\
{[0.09]}\end{array}$ & $\begin{array}{c}1.00 \\
{[1.00]}\end{array}$ \\
\hline
\end{tabular}

Sources: Economic Freedom of the World (1970-2015), Fraser Institute (www.fraserinstitute.org/economic-freedom) for the dependent variable and respective areas. Database of Political Institutions (1975-2015), World Bank (http://www.worldbank.org), and Comparative Political Data Set (1960-2016) for the political variables (http://www.cpds-data.org/). The quality of democracy index comes from the Polity IV project (1960-2016) database, Center for Systemic Peace (www.systemicpeace.org). For the economic variables, data were gathered from the World Development Indicators (1960-2016), World Bank (http://www.worldbank.org). Data for FinCrisis were obtained from Laeven and Valencia (2018) and Nguyen et al. (2020). The education index comes from the Human Development Reports (1990-2015), United Nations Development Programme (http://hdr.undp.org).

Notes: Descriptive statistics for the 106 countries considered in the estimations over the periods 2000-2015 (without brackets) and 1975-2015 (in square brackets). The countries used in the estimations are the following (OECD countries in italic): Albania, Algeria, Argentina, Armenia, Australia, Austria, Azerbaijan, Bangladesh, Belgium, Benin, Bolivia, Bosnia, Botswana, Brazil, Bulgaria, Burkina Faso, Burundi, Cameroon, Canada, Chile, Colombia, Republic of Congo, Costa Rica, Cote d'Ivoire, Croatia, Cyprus, Czech Republic, Denmark, Dominican Republic, Ecuador, Egypt, El Salvador, Estonia, Finland, France, Gabon, Georgia, Germany, Ghana, Greece, Guatemala, Guyana, Haiti, Honduras, Hungary, India, Indonesia, Ireland, Israel, Italy, Jamaica, Japan, Kenya, Korea, Kyrgyz Republic, Latvia, Lithuania, Luxembourg, Madagascar, Malawi, Malaysia, Mali, Mauritius, Mexico, Mongolia, Morocco, Mozambique, Namibia, Netherlands, New Zealand, Nicaragua, Niger, Nigeria, Norway, Pakistan, Panama, Paraguay, Peru, Philippines, Poland, Portugal, Romania, Russia, Senegal, Sierra Leone, Singapore, Slovak Republic, Slovenia, South Africa, Spain, Sri Lanka, Sweden, Switzerland, Tanzania, Thailand, Togo, Trinidad and Tobago, Tunisia, Turkey, Ukraine, United Kingdom, United States, Uruguay, Venezuela, Zambia, Zimbabwe. 
Table 2. The impact of government ideology on economic freedom (2000-2015)

\begin{tabular}{|c|c|c|c|c|c|c|}
\hline & (1) & (2) & (3) & (4) & (5) & (6) \\
\hline L.EconFreedom & $\begin{array}{c}0.8197 * * * \\
(0.0511)\end{array}$ & $\begin{array}{c}0.8217 * * * \\
(0.0528)\end{array}$ & $\begin{array}{c}0.8105 * * * \\
(0.0556)\end{array}$ & $\begin{array}{c}0.8202 * * * \\
(0.0511)\end{array}$ & $\begin{array}{c}0.8548 * * * \\
(0.0438)\end{array}$ & $\begin{array}{c}0.8586 * * * \\
(0.0441)\end{array}$ \\
\hline Right & $\begin{array}{c}0.0469 * * * \\
(0.0167)\end{array}$ & $\begin{array}{c}0.0474 * * * \\
(0.0175)\end{array}$ & & $\begin{array}{c}0.0556^{* *} \\
(0.0274)\end{array}$ & $\begin{array}{c}0.0343 * * \\
(0.0159)\end{array}$ & \\
\hline Centre & & $\begin{array}{c}0.0025 \\
(0.0292)\end{array}$ & & & & \\
\hline Left & & & $\begin{array}{l}-0.0153 \\
(0.0223)\end{array}$ & & & \\
\hline Election & $\begin{array}{c}0.0047 \\
(0.0095)\end{array}$ & $\begin{array}{c}0.0044 \\
(0.0096)\end{array}$ & $\begin{array}{c}0.0040 \\
(0.0091)\end{array}$ & $\begin{array}{c}0.0049 \\
(0.0094)\end{array}$ & $\begin{array}{c}0.0112 \\
(0.0097)\end{array}$ & $\begin{array}{c}0.0105 \\
(0.00984)\end{array}$ \\
\hline MajGov & $\begin{array}{c}0.0014 \\
(0.0163)\end{array}$ & $\begin{array}{c}0.0001 \\
(0.0163)\end{array}$ & $\begin{array}{l}-0.0008 \\
(0.0172)\end{array}$ & $\begin{array}{c}0.0056 \\
(0.0192)\end{array}$ & $\begin{array}{c}0.0070 \\
(0.0162)\end{array}$ & $\begin{array}{c}0.0043 \\
(0.0153)\end{array}$ \\
\hline Maj $\times$ Right & & & & $\begin{array}{l}-0.0110 \\
(0.0274)\end{array}$ & & \\
\hline TimeOffice & & & & & $\begin{array}{l}-0.0015 \\
(0.0011)\end{array}$ & \\
\hline Office $\times$ Right & & & & & $\begin{array}{c}0.0003 \\
(0.0012)\end{array}$ & \\
\hline RightTerm $=1$ & & & & & & $\begin{array}{c}0.0483 * * * \\
(0.0184)\end{array}$ \\
\hline RightTerm $>1$ & & & & & & $\begin{array}{l}0.0263 * \\
(0.0158)\end{array}$ \\
\hline Democracy & $\begin{array}{l}0.0009 * \\
(0.0005)\end{array}$ & $\begin{array}{l}0.0009 * \\
(0.0005)\end{array}$ & $\begin{array}{l}0.0009 * \\
(0.0005)\end{array}$ & $\begin{array}{c}0.0009 \\
(0.0006)\end{array}$ & $\begin{array}{l}0.0014 * \\
(0.0008)\end{array}$ & $\begin{array}{l}0.0014 * \\
(0.0005)\end{array}$ \\
\hline $\operatorname{LnGDPpc}$ & $\begin{array}{c}0.0003 \\
(0.0231)\end{array}$ & $\begin{array}{c}0.0005 \\
(0.0236)\end{array}$ & $\begin{array}{l}0.0088 \\
0.0251\end{array}$ & $\begin{array}{c}0.0005 \\
(0.0230)\end{array}$ & $\begin{array}{l}-0.0017 \\
(0.0209)\end{array}$ & $\begin{array}{l}-0.0005 \\
(0.0201)\end{array}$ \\
\hline Trade & $\begin{array}{c}0.0006 * * \\
(0.0002)\end{array}$ & $\begin{array}{c}0.0006 * * \\
(0.0003)\end{array}$ & $\begin{array}{c}0.0005^{* *} \\
(0.0002)\end{array}$ & $\begin{array}{c}0.0006 * * * \\
(0.0002)\end{array}$ & $\begin{array}{c}0.0006 * * * \\
(0.0002)\end{array}$ & $\begin{array}{c}0.0005^{* *} \\
(0.0002)\end{array}$ \\
\hline FinCrisis & $\begin{array}{c}-0.0735 * * * \\
(0.0164)\end{array}$ & $\begin{array}{c}-0.0740 * * * \\
(0.0176)\end{array}$ & $\begin{array}{c}-0.0771 * * * \\
(0.0182)\end{array}$ & $\begin{array}{c}-0.0732 * * * \\
(0.0164)\end{array}$ & $\begin{array}{c}-0.0675^{* * *} * \\
(0.0167)\end{array}$ & $\begin{array}{c}-0.0696 * * * \\
(0.0164)\end{array}$ \\
\hline Education & $\begin{array}{c}0.4196 * * * \\
(0.1370)\end{array}$ & $\begin{array}{c}0.4083 * * * \\
(0.1488)\end{array}$ & $\begin{array}{c}0.4116^{* * *} \\
(0.1490)\end{array}$ & $\begin{array}{c}0.4176 * * * \\
(0.1367)\end{array}$ & $\begin{array}{c}0.2985 * * \\
(0.1306)\end{array}$ & $\begin{array}{c}0.3267 * * * \\
(0.1315)\end{array}$ \\
\hline Trend & $\begin{array}{l}-0.0022 \\
(0.0014) \\
\end{array}$ & $\begin{array}{l}-0.0021 \\
(0.0015)\end{array}$ & $\begin{array}{l}-0.0025 \\
(0.0015) \\
\end{array}$ & $\begin{array}{l}-0.0021 \\
(0.0015)\end{array}$ & $\begin{array}{l}-0.0019 \\
(0.0013)\end{array}$ & $\begin{array}{l}-0.0019 \\
(0.0013)\end{array}$ \\
\hline Observations & 1478 & 1478 & 1478 & 1478 & 1360 & 1360 \\
\hline Countries & 106 & 106 & 106 & 106 & 101 & 101 \\
\hline Instruments & 95 & 96 & 95 & 96 & 97 & 96 \\
\hline AR1 & 0.0000 & 0.0000 & 0.0000 & 0.0000 & 0.0000 & 0.0000 \\
\hline AR2 & 0.7294 & 0.7335 & 0.7421 & 0.7255 & 0.0952 & 0.1012 \\
\hline Hansen & 0.2560 & 0.2333 & 0.2432 & 0.2706 & 0.3694 & 0.3873 \\
\hline Diff-Hansen 1 & 0.2391 & 0.2165 & 0.2607 & 0.2560 & 0.3555 & 0.3580 \\
\hline Diff-Hansen2 & 0.5038 & 0.5107 & 0.2367 & 0.4750 & 0.4579 & 0.5989 \\
\hline \multicolumn{7}{|c|}{$\begin{array}{l}\text { Notes: See Table } 1 \text { for the definition of the variables. Two-step system-GMM estimations using robust standard errors corrected } \\
\text { for finite samples (standard errors in parentheses). Significance levels at which the null hypothesis is rejected: ***, } 1 \% ; *, 5 \% \text {; } \\
\text { and } *, 10 \% \text {. The lag of the dependent variable and Democracy are treated as endogenous in the GMM estimations; the respective } \\
\text { lagged values and the other explanatory variables are used as instruments in the first-difference equation and their differences are } \\
\text { used in the levels equation; they were collapsed to avoid the problem of having too many instruments. The values reported for } \\
\text { AR(1) and AR(2) are the } p \text {-values of the Arellano-Bond tests for first and second order auto-correlated disturbances in the first } \\
\text { differences equations. The Hansen test reports the } p \text {-value for the null hypothesis of instrument validity; Diff-Hansen } 1 \text { tests the } \\
\text { exogeneity of the instruments used in the level part (of the system) as a whole. Diff-Hansen } 2 \text { tests the exogeneity of the lagged } \\
\text { level of economic freedom used as an instrument in the level part. RightTerm=1 (RightTerm }>1 \text { ) is a dummy variable that takes the } \\
\text { value of } 1 \text { for the first term (remaining terms) a right-wing government is in office; zero, otherwise. }\end{array}$} \\
\hline
\end{tabular}


Table 3. A closer look on the ideological effects on economic freedom (2000-2015)

\begin{tabular}{|c|c|c|c|c|c|c|}
\hline & (1) & (2) & (3) & (4) & (5) & (6) \\
\hline L.EconFreedom & $\begin{array}{c}0.8175^{* * *} \\
(0.0514)\end{array}$ & $\begin{array}{c}0.8051 * * * \\
(0.0570)\end{array}$ & $\begin{array}{c}0.7822 * * * \\
(0.0307)\end{array}$ & $\begin{array}{c}0.7801 * * * \\
(0.0313)\end{array}$ & $\begin{array}{c}0.8210 * * * \\
(0.0482)\end{array}$ & $\begin{array}{c}0.7256 * * * \\
(0.0649)\end{array}$ \\
\hline EstabRight & $\begin{array}{c}0.0495^{* * *} * \\
(0.0184)\end{array}$ & & & & & \\
\hline PopRight & $\begin{array}{c}0.0260 \\
(0.0321)\end{array}$ & & & & & \\
\hline EstabLeft & & $\begin{array}{c}0.0018 \\
(0.0243)\end{array}$ & & & & \\
\hline PopLeft & & $\begin{array}{c}-0.0869 * * \\
(0.0413)\end{array}$ & & & & \\
\hline HegRight & & & $\begin{array}{c}0.0433 * * * \\
(0.0155)\end{array}$ & & & \\
\hline DomRight & & & $\begin{array}{c}0.0222 \\
(0.0174)\end{array}$ & & & \\
\hline HegLeft & & & & $\begin{array}{l}-0.0334 \\
(0.0213)\end{array}$ & & \\
\hline DomLeft & & & & $\begin{array}{c}-0.0518 * * \\
(0.0254)\end{array}$ & & \\
\hline Right & & & & & $\begin{array}{c}0.0701 * * \\
(0.0315)\end{array}$ & $\begin{array}{c}0.1743 * * \\
(0.0763)\end{array}$ \\
\hline$O E C D$ & & & & & $\begin{array}{c}0.0964 * * \\
(0.0433)\end{array}$ & \\
\hline$O E C D \times$ Right & & & & & $\begin{array}{c}-0.0589 \\
(0.0402)\end{array}$ & \\
\hline CIE & & & & & & $\begin{array}{c}0.0582 * * * \\
(0.0212)\end{array}$ \\
\hline$C I E \times$ Right & & & & & & $\begin{array}{c}-0.0286^{* *} \\
(0.0132)\end{array}$ \\
\hline Observations & 1478 & 1478 & 507 & 507 & 1478 & 941 \\
\hline Countries & 106 & 106 & 34 & 34 & 106 & 105 \\
\hline
\end{tabular}

Notes: Columns 1, 2, 5 and 6 report two-step system-GMM estimations using robust standard errors corrected for finite samples (standard errors in parentheses); regressions 3 and 4 were performed using Bruno's LSDVC estimator. Significance levels at which the null hypothesis is rejected: ***, 1\%;**, 5\%; and *, 10\%. The lag of the dependent variable and Democracy are treated as endogenous in the GMM estimations as in the estimations in Table 2. The estimations include the same political and socio-economic controllers used in Table 2. The results for those controllers have proven to be very similar as well as the results of the GMM tests. They are not reported here to save space, but they are available upon request. The Blundell-Bond procedure is used as the initial estimator in the LSDVC estimations; 100 repetitions of the procedure to bootstrap the estimated standard errors were undertaken. Regressions 3 and 4 use data from the CPDS database for government orientation. Separate estimations for non-OECD and OECD countries are reported in columns 6 and 7, respectively. Estab\# (Pop\#) correspond to dummies that take the value of one when an ideologically established (populist) right-wing or left-wing party is in office. Heg\# (Dom\#) correspond to dummies that take the value of one when there is hegemony (dominance) of right-wing or left-wing parties in office. $O E C D$ is a dummy that takes value of one when the country belongs to the OECD. CIE is the index of Contract Intensive Economy as defined by Mousseau (2012). 
Table 4. Effects of government ideology on the broad areas of economic freedom (2000-2015)

\begin{tabular}{|c|c|c|c|c|c|}
\hline & $\begin{array}{c}\text { SizeGov } \\
(1) \\
\end{array}$ & $\begin{array}{c}\text { LegalSystem } \\
(2)\end{array}$ & $\begin{array}{c}\text { SoundMoney } \\
\text { (3) } \\
\end{array}$ & $\begin{array}{c}\text { Freedom Trade } \\
\text { (4) }\end{array}$ & $\begin{array}{c}\text { Regulation } \\
\text { (5) }\end{array}$ \\
\hline L.DepVar & $\begin{array}{c}0.7854 * * * \\
(0.0523)\end{array}$ & $\begin{array}{c}0.6496 * * * \\
(0.0625)\end{array}$ & $\begin{array}{c}0.6936 * * * \\
(0.0948)\end{array}$ & $\begin{array}{c}0.7941 * * * \\
(0.0451)\end{array}$ & $\begin{array}{c}0.6322 * * * \\
(0.0663)\end{array}$ \\
\hline Right & $\begin{array}{c}0.0053 \\
(0.0407)\end{array}$ & $\begin{array}{c}0.0308 \\
(0.0561)\end{array}$ & $\begin{array}{c}0.1327 * * * \\
(0.0482)\end{array}$ & $\begin{array}{c}0.0450 * * \\
(0.0218)\end{array}$ & $\begin{array}{c}0.0786^{* *} \\
(0.0372)\end{array}$ \\
\hline Election & $\begin{array}{l}-0.0144 \\
(0.0253)\end{array}$ & $\begin{array}{c}0.0118 \\
(0.0187)\end{array}$ & $\begin{array}{c}0.0143 \\
(0.0197)\end{array}$ & $\begin{array}{c}0.0027 \\
(0.0169)\end{array}$ & $\begin{array}{l}-0.0039 \\
(0.0156)\end{array}$ \\
\hline MajGov & $\begin{array}{l}-0.0601 \\
(0.0377)\end{array}$ & $\begin{array}{c}0.0371 \\
(0.0509)\end{array}$ & $\begin{array}{c}0.0245 \\
(0.0461)\end{array}$ & $\begin{array}{l}-0.0075 \\
(0.0249)\end{array}$ & $\begin{array}{c}0.0434 \\
(0.0322)\end{array}$ \\
\hline Democracy & $\begin{array}{c}-0.0018 \\
(0.0019)\end{array}$ & $\begin{array}{c}0.0049 * * * \\
(0.0014)\end{array}$ & $\begin{array}{c}0.0015 \\
(0.0019)\end{array}$ & $\begin{array}{c}0.0012 \\
(0.0017)\end{array}$ & $\begin{array}{l}-0.0005 \\
(0.0011)\end{array}$ \\
\hline $\operatorname{LnGDPpc}$ & $\begin{array}{c}-0.1467 * * * \\
(0.0469)\end{array}$ & $\begin{array}{c}0.1924 * * * \\
(0.0723)\end{array}$ & $\begin{array}{c}0.0832 \\
(0.0596)\end{array}$ & $\begin{array}{c}0.0125 \\
(0.0310)\end{array}$ & $\begin{array}{c}0.0290 \\
(0.0416)\end{array}$ \\
\hline Trade & $\begin{array}{c}0.0002 \\
(0.0008)\end{array}$ & $\begin{array}{l}0.0013 * * \\
(0.0006)\end{array}$ & $\begin{array}{c}0.0002 \\
(0.0004)\end{array}$ & $\begin{array}{c}0.0012 * * * \\
(0.0003)\end{array}$ & $\begin{array}{c}0.0016 * * * \\
(0.0006)\end{array}$ \\
\hline FinCrisis & $\begin{array}{c}-0.0821 * * \\
(0.0383)\end{array}$ & $\begin{array}{l}-0.0766^{*} \\
(0.0453)\end{array}$ & $\begin{array}{l}-0.1211^{* *} \\
(0.0531)\end{array}$ & $\begin{array}{c}-0.0934 * * * \\
(0.0279)\end{array}$ & $\begin{array}{c}-0.0893 * * \\
(0.0370)\end{array}$ \\
\hline Education & $\begin{array}{c}0.4239 \\
(0.2870)\end{array}$ & $\begin{array}{l}0.7999 * * \\
(0.3491)\end{array}$ & $\begin{array}{c}0.6062 \\
(0.4118)\end{array}$ & $\begin{array}{c}0.4179 * \\
(0.2208)\end{array}$ & $\begin{array}{l}0.7672 * * \\
(0.3302)\end{array}$ \\
\hline Trend & $\begin{array}{l}-0.0031 \\
(0.0032)\end{array}$ & $\begin{array}{l}-0.0067 * \\
(0.0035)\end{array}$ & $\begin{array}{c}0.0044 \\
(0.0041)\end{array}$ & $\begin{array}{l}0.0042 * \\
(0.0025)\end{array}$ & $\begin{array}{c}0.0050 \\
(0.0037)\end{array}$ \\
\hline Observations & 1478 & 1478 & 1478 & 1478 & 1478 \\
\hline Countries & 106 & 106 & 106 & 106 & 106 \\
\hline Instruments & 95 & 95 & 95 & 95 & 95 \\
\hline AR1 & 0.0000 & 0.0000 & 0.0000 & 0.0000 & 0.0000 \\
\hline AR2 & 0.9472 & 0.3500 & 0.1498 & 0.1411 & 0.4242 \\
\hline Hansen & 0.2288 & 0.1411 & 0.2054 & 0.1449 & 0.1474 \\
\hline Diff-Hansen 1 & 0.1932 & 0.1126 & 0.1782 & 0.1284 & 0.1237 \\
\hline Diff-Hansen2 & 0.8166 & 0.9028 & 0.6913 & 0.5803 & 0.7363 \\
\hline
\end{tabular}


Table 5. The impact of government ideology on economic freedom (1975-2015)

\begin{tabular}{|c|c|c|c|c|c|c|}
\hline & $(1)$ & $(2)$ & (3) & (4) & (5) & $(6)$ \\
\hline L.EconFreedom & $\begin{array}{c}0.2301 * * \\
(0.1162)\end{array}$ & $\begin{array}{c}0.4088 * * * \\
(0.0643)\end{array}$ & $\begin{array}{c}0.1443 * * \\
(0.0737)\end{array}$ & $\begin{array}{c}0.2128 * * * \\
(0.0553)\end{array}$ & $\begin{array}{c}0.1609 * * \\
(0.0699)\end{array}$ & $\begin{array}{c}0.1490 * * * \\
(0.0521)\end{array}$ \\
\hline Right & $\begin{array}{c}0.1426^{* *} \\
(0.0569)\end{array}$ & $\begin{array}{c}0.1248 * * * \\
(0.0380)\end{array}$ & $\begin{array}{c}0.1077 * * \\
(0.0504)\end{array}$ & $\begin{array}{c}0.0974 * * * \\
(0.0379)\end{array}$ & $\begin{array}{c}0.1335^{* *} \\
(0.0569)\end{array}$ & $\begin{array}{c}0.1437 * * \\
(0.0551)\end{array}$ \\
\hline Election & $\begin{array}{c}0.0145 \\
(0.0223)\end{array}$ & $\begin{array}{c}0.0168 \\
(0.0106)\end{array}$ & $\begin{array}{c}0.0343 \\
(0.0393)\end{array}$ & $\begin{array}{c}0.0357 \\
(0.0274)\end{array}$ & $\begin{array}{c}0.0328 \\
(0.0397)\end{array}$ & $\begin{array}{l}-0.0283 \\
(0.0433)\end{array}$ \\
\hline MajGov & $\begin{array}{l}-0.0253 \\
(0.0486)\end{array}$ & $\begin{array}{l}-0.0181 \\
(0.0309)\end{array}$ & $\begin{array}{l}-0.0690 \\
(0.0491)\end{array}$ & $\begin{array}{l}-0.0597 \\
(0.0365)\end{array}$ & $\begin{array}{l}-0.0712 \\
(0.0477)\end{array}$ & $\begin{array}{c}0.0529 \\
(0.0558)\end{array}$ \\
\hline Democracy & $\begin{array}{l}-0.0008 \\
(0.0010)\end{array}$ & $\begin{array}{c}0.0006 \\
(0.0008)\end{array}$ & $\begin{array}{c}0.0008 \\
(0.0021)\end{array}$ & $\begin{array}{c}0.0008 \\
(0.0014)\end{array}$ & $\begin{array}{c}0.0006 \\
(0.0021)\end{array}$ & $\begin{array}{c}0.0408 \\
(0.1022)\end{array}$ \\
\hline $\operatorname{LnGDPpc}$ & $\begin{array}{l}0.1187^{*} \\
(0.0684)\end{array}$ & $\begin{array}{l}0.0859^{*} \\
(0.0497)\end{array}$ & $\begin{array}{c}0.2801 * * * \\
(0.0426)\end{array}$ & $\begin{array}{c}0.2587 * * * \\
(0.0317)\end{array}$ & $\begin{array}{c}0.2033 * * * \\
(0.0565)\end{array}$ & $\begin{array}{c}0.8545^{* *} * \\
(0.3681)\end{array}$ \\
\hline Trade & $\begin{array}{c}0.0022 * * \\
(0.0009)\end{array}$ & $\begin{array}{c}0.0016^{* *} \\
(0.0007)\end{array}$ & $\begin{array}{c}0.0027^{* * *} \\
(0.0009)\end{array}$ & $\begin{array}{c}0.0024 * * * \\
(0.0007)\end{array}$ & $\begin{array}{c}0.0032^{* * *} * \\
(0.0010)\end{array}$ & $\begin{array}{l}-0.0041 \\
(0.0121)\end{array}$ \\
\hline FinCrisis & $\begin{array}{c}-0.1769 * * * \\
(0.0610)\end{array}$ & $\begin{array}{c}-0.1561 * * * \\
(0.0402)\end{array}$ & $\begin{array}{c}-0.2531 * * * \\
(0.0816)\end{array}$ & $\begin{array}{c}-0.2344^{* * *} \\
(0.0515)\end{array}$ & $\begin{array}{c}-0.2528 * * * \\
(0.0797)\end{array}$ & $\begin{array}{c}-0.1644^{* *} \\
(0.0733)\end{array}$ \\
\hline Education & $\begin{array}{c}1.2503 * * \\
(0.5296)\end{array}$ & $\begin{array}{c}0.9717 * * * \\
(0.3827)\end{array}$ & & & & \\
\hline Trend & $\begin{array}{c}0.0010 \\
(0.0053)\end{array}$ & $\begin{array}{l}-0.0008 \\
(0.0038)\end{array}$ & $\begin{array}{c}0.0225^{* * * *} \\
(0.0033)\end{array}$ & $\begin{array}{c}0.0208^{* * * *} \\
(0.0027)\end{array}$ & $\begin{array}{c}0.0234^{* * * *} \\
(0.0033)\end{array}$ & $\begin{array}{c}0.0189 * * * \\
(0.0070)\end{array}$ \\
\hline$O E C D$ & & & & & $\begin{array}{l}0.3073 * \\
(0.1661)\end{array}$ & \\
\hline$O E C D \times$ Right & & & & & $\begin{array}{l}-0.0459 \\
(0.1225)\end{array}$ & \\
\hline Observations & 1768 & 1768 & 2535 & 2535 & 2535 & 1053 \\
\hline Countries & 106 & 106 & 106 & 106 & 106 & 34 \\
\hline Instruments & 95 & 95 & 94 & 94 & 96 & \\
\hline AR1 & 0.0000 & 0.0000 & 0.0000 & 0.0000 & 0.0000 & \\
\hline AR2 & 0.2506 & 0.6721 & 0.5158 & 0.3372 & 0.5308 & \\
\hline Hansen & 0.3176 & 0.3902 & 0.2876 & 0.2807 & 0.3264 & \\
\hline Diff-Hansen1 & 0.3654 & 0.3997 & 0.3028 & 0.2673 & 0.3424 & \\
\hline Diff-Hansen2 & 0.2102 & 0.3048 & 0.2962 & 0.4639 & 0.2796 & \\
\hline
\end{tabular}

Notes: See Table 1 for the definition of the variables. The estimated coefficients, respective standard errors and additional statistics in columns 1, 3 and 5-6 were obtained from the estimation of five models using five imputations of EconFreedom; we follow King et al. (2001) to obtain the five imputations for the EconFreedom series and compute the estimates reported in this table as suggested by King et al. (2001, p. 53). The results in columns 2 and 4 were obtained from a single estimation where the average of the imputations of EconFreedom is used instead. Two-step system-GMM estimations using robust standard errors corrected for finite samples were employed for the estimation of models 1-5; for model 6 a panel FE estimator was used instead. Significance levels at which the null hypothesis is rejected: ***, $1 \% ; * *, 5 \%$; and *, 10\%. The lag of the dependent variable and Democracy are treated as endogenous in the GMM estimations; the respective lagged values and the other explanatory variables are used as instruments in the first-difference equation and their differences are used in the levels equation; they were collapsed to avoid the problem of having too many instruments. The values reported for AR(1) and $\mathrm{AR}(2)$ are the $p$-values of the Arellano-Bond tests for first and second order auto-correlated disturbances in the first differences equations. The Hansen test reports the $p$-value for the null hypothesis of instrument validity; Diff-Hansen1 tests the exogeneity of the instruments used in the level part (of the system) as a whole. Diff-Hansen 2 tests the exogeneity of the lagged level of economic freedom used as an instrument in the level part. Regression 6 uses data from the CPDS database for the variable Right (which is equal to HegRight plus DomRight). 
Table 6. Effects of government ideology on the broad areas of economic freedom (1975-2015)

\begin{tabular}{lccccc}
\hline & $\begin{array}{c}\text { SizeGov } \\
(\mathbf{1})\end{array}$ & $\begin{array}{c}\text { LegalSystem } \\
(\mathbf{2})\end{array}$ & $\begin{array}{c}\text { SoundMoney } \\
\mathbf{( 3 )}\end{array}$ & $\begin{array}{c}\text { FreedomTrade } \\
\mathbf{( 4 )}\end{array}$ & $\begin{array}{c}\text { Regulation } \\
(\mathbf{5})\end{array}$ \\
\hline L.DepVar & $0.0861^{*}$ & $0.0788^{*}$ & $0.1214^{* *}$ & $0.1004^{*}$ & $0.1105^{* *}$ \\
& $(0.0506)$ & $(0.0434)$ & $(0.0619)$ & $(0.0554)$ & $(0.0504)$ \\
Right & 0.0548 & 0.0418 & $0.1789^{* *}$ & $0.1386^{*}$ & $0.1433^{* *}$ \\
& $(0.1259)$ & $(0.0924)$ & $(0.0846)$ & $(0.0739)$ & $(0.0718)$ \\
Election & 0.0567 & 0.0291 & 0.0403 & 0.0230 & 0.0104 \\
& $(0.0718)$ & $(0.0383)$ & $(0.0456)$ & $(0.0547)$ & $(0.0355)$ \\
MajGov & -0.1482 & -0.0250 & -0.0254 & $-0.1881^{* *}$ & 0.0365 \\
& $(0.1085)$ & $(0.0907)$ & $(0.1023)$ & $(0.0727)$ & $(0.0656)$ \\
Democracy & -0.0040 & $0.0070^{* *}$ & -0.0009 & 0.0007 & 0.0004 \\
& $(0.0040)$ & $(0.0029)$ & $(0.0031)$ & $(0.0032)$ & $(0.0030)$ \\
LnGDPpc & $-0.3403^{* * *}$ & $0.7756^{* * *}$ & $0.4393^{* * *}$ & $0.3657^{* * *}$ & $0.2512^{* * *}$ \\
& $(0.0754)$ & $(0.0733)$ & $(0.0608)$ & $(0.0410)$ & $(0.0426)$ \\
Trade & 0.0022 & $0.0023^{* *}$ & 0.0012 & $0.0045^{* * *}$ & $0.0041^{* * *}$ \\
& $(0.0027)$ & $(0.0011)$ & $(0.0012)$ & $(0.0008)$ & $(0.0009)$ \\
FinCrisis & $-0.2022^{* *}$ & $-0.2330^{* *}$ & $-0.4062^{* * *}$ & $-0.2750^{* *}$ & $-0.2577^{* * *}$ \\
& $(0.0966)$ & $(0.0959)$ & $(0.1309)$ & $(0.1145)$ & $(0.0818)$ \\
Trend & $0.0227^{* * *}$ & 0.0065 & $0.0417^{* * *}$ & $0.0236^{* * *}$ & $0.01933^{* * *}$ \\
& $(0.0059)$ & $(0.0041)$ & $(0.0063)$ & $(0.0049)$ & $(0.0034)$ \\
\hline Observations & 2535 & 2535 & 2535 & 2535 & 2535 \\
Countries & 106 & 106 & 106 & 106 & 106 \\
Instruments & 94 & 94 & 94 & 94 & 94 \\
AR1 & 0.0000 & 0.0000 & 0.0000 & 0.0000 & 0.0000 \\
AR2 & 0.5152 & 0.6536 & 0.5666 & 0.4218 & 0.4360 \\
Hansen & 0.2434 & 0.2300 & 0.3124 & 0.3108 & 0.2922 \\
Diff-Hansen1 & 0.3060 & 0.2510 & 0.3494 & 0.2800 & 0.3030 \\
Diff-Hansen2 & 0.2256 & 0.3176 & 0.2948 & 0.6990 & 0.4082 \\
\hline Notes: Sec Tan &
\end{tabular}

Notes: See Table 1 for the definition of the variables. L.DepVar corresponds to the lag of the dependent variable for the respective area of economic freedom. The estimated coefficients, respective standard errors and additional statistics were obtained from the estimation of five models using five imputations of each dependent variable; we follow King et al. (2001) to obtain the five imputations for each dependent variable series and compute the estimates reported in this table as suggested by King et al. (2001, p. 53). Two-step system-GMM estimations using robust standard errors corrected for finite samples were employed in the estimations; see Table 4 for technical details. 


\section{FIGURES}

Figure 1. Average Economic Freedom index by Political Orientation of the Government

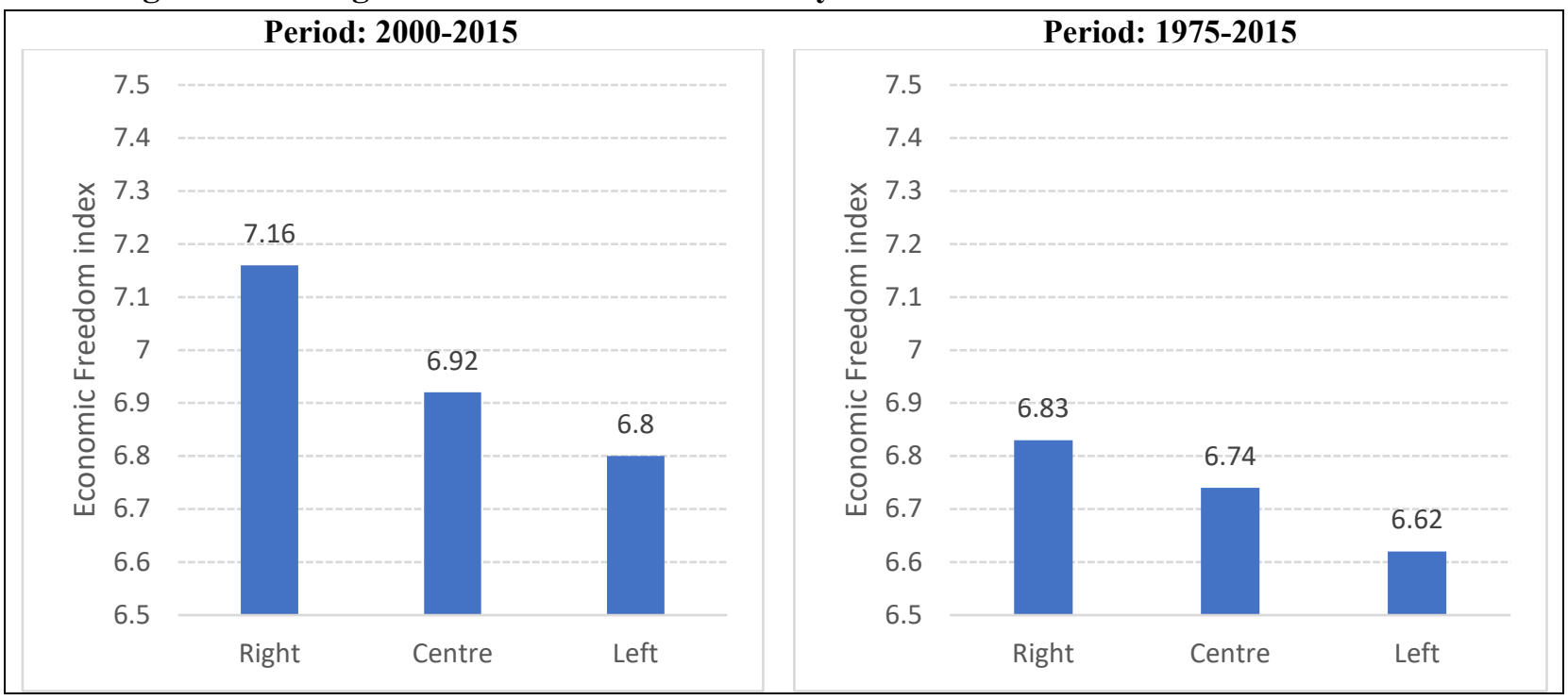

Figure 2. Relationship between political ideology and economic freedom

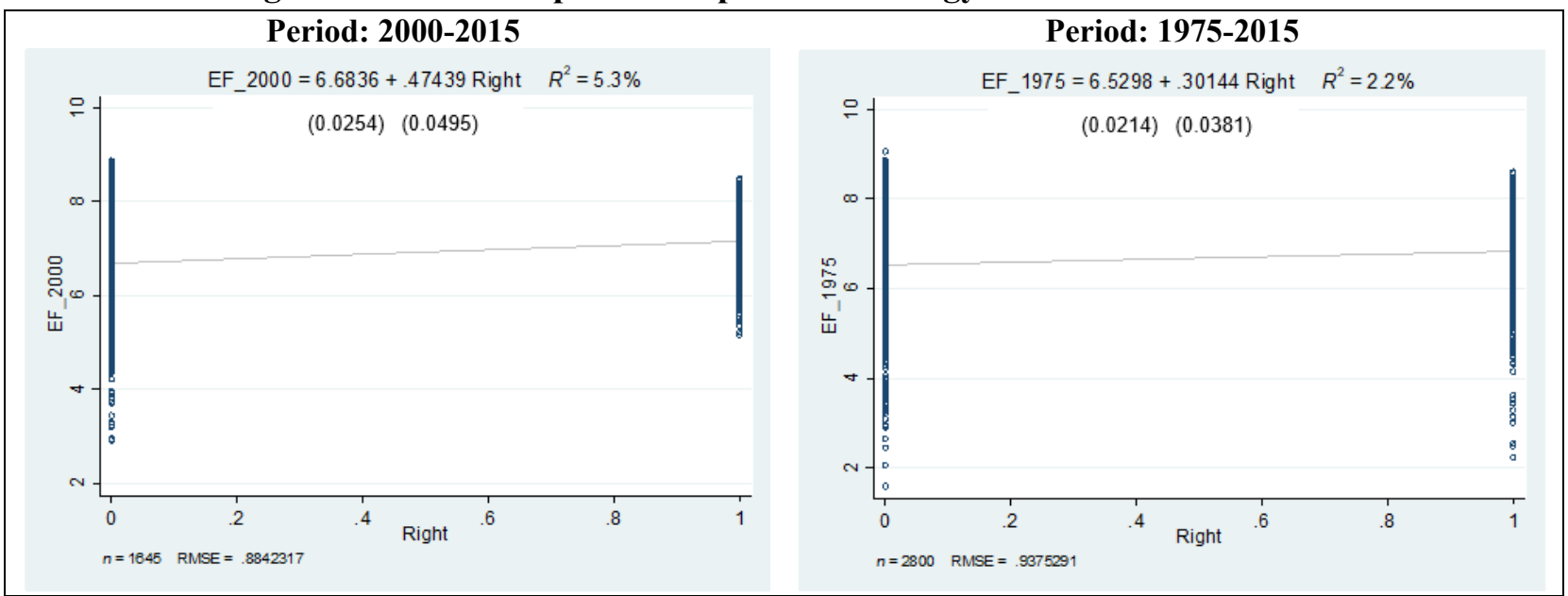

Notes: Standard errors are reported in parentheses for each coefficient. 


\section{ANNEX}

Table A.1. Broad areas of Economic Freedom

Area

Size of government
(SizeGov)

Legal System and

Property Rights

(LegalSystem)

Sound Money

(SoundMoney)

Freedom to Trade Internationally

(FreedomTrade)

Regulation

(Regulation)
Description

As the size of the government increases, in terms of government spending, taxation, government-controlled enterprises, etc., centralized decision-making replaces individual choices and economic freedom is reduced; countries with smaller governments register higher ratings in this area.

Measures the importance of the legal system as a determinant of economic freedom; countries where the rule of law prevails, protection of persons and their rightfully acquired property is guaranteed, the judiciary system is independent and unbiased and there is an effective and impartial enforcement of the law will score better in this area.

It focuses on the importance of money and relative price stability in the exchange process; sound money reduces transaction costs and facilitates exchange, thereby promoting economic freedom; so to score high in this area, a country must follow policies and adopt institutions that lead to low (and stable) rates of inflation and avoid regulations that limit the ability to use alternative currencies.

When governments impose restrictions that reduce the ability of their residents to engage in voluntary exchange with people in other countries, economic freedom is diminished; countries with low tariffs, easy clearance and efficient administration of customs, a freely convertible currency, and few controls on the movement of physical and human capital will score higher in this area.

It measures how regulations restrict entry into markets and limit the freedom of exchange in credit, labour, and product markets; countries facing these regulatory constraints will score lower in this area.

Source: See Gwartney et al. (2017).

Table A.2. Correlation matrix

\begin{tabular}{|c|c|c|c|c|c|c|c|c|c|c|c|c|c|c|c|c|}
\hline \multirow[b]{2}{*}{ Variables } & \multirow[b]{2}{*}{ (1) } & & & & & \multicolumn{11}{|c|}{ Correlations for total time period } \\
\hline & & $(2)$ & (3) & $(4)$ & $(5)$ & $(6)$ & $(7)$ & $(8)$ & (9) & $(10)$ & (11) & (12) & (13) & $(14)$ & $(15)$ & (16) \\
\hline (1)EconFreedom & 1 & 0.251 & 0.737 & 0.835 & 0.864 & 0.808 & 0.168 & 0.045 & 0.050 & -0.042 & -0.132 & 0.490 & 0.559 & 0.383 & -0.371 & 0.657 \\
\hline (2)SizeGov & 0.164 & 1 & -0.276 & 0.052 & 0.049 & 0.101 & -0.067 & -0.006 & -0.005 & -0.064 & -0.023 & -0.099 & -0.376 & 0.105 & 0.062 & -0.264 \\
\hline (3)LegalSystem & 0.781 & -0.292 & 1 & 0.531 & 0.635 & 0.632 & 0.213 & 0.078 & 0.052 & -0.005 & -0.052 & 0.482 & 0.804 & 0.267 & -0.376 & 0.735 \\
\hline (4)SoundMoney & 0.823 & -0.032 & 0.546 & 1 & 0.730 & 0.564 & 0.124 & 0.018 & 0.050 & -0.021 & -0.107 & 0.420 & 0.446 & 0.211 & -0.320 & 0.537 \\
\hline (5)FreedomTrade & 0.869 & -0.010 & 0.667 & 0.733 & 1 & 0.620 & 0.147 & 0.042 & 0.044 & -0.092 & -0.143 & 0.498 & 0.535 & 0.377 & -0.331 & 0.608 \\
\hline (6)Regulation & 0.796 & -0.002 & 0.674 & 0.529 & 0.612 & 1 & 0.162 & 0.014 & 0.026 & 0.051 & -0.114 & 0.395 & 0.480 & 0.409 & -0.332 & 0.572 \\
\hline (7)Right & 0.249 & -0.046 & 0.223 & 0.227 & 0.234 & 0.196 & 1 & -0.224 & 0.030 & -0.044 & -0.063 & 0.231 & 0.236 & -0.060 & -0.076 & 0.177 \\
\hline (8)Centre & 0.124 & 0.004 & 0.110 & 0.110 & 0.113 & 0.073 & -0.184 & 1 & 0.011 & -0.026 & 0.027 & 0.127 & 0.071 & 0.045 & -0.037 & 0.103 \\
\hline (9)Elections & 0.036 & -0.022 & 0.038 & 0.043 & 0.035 & 0.020 & 0.030 & 0.014 & 1 & -0.041 & 0.041 & 0.082 & 0.059 & -0.021 & -0.025 & 0.062 \\
\hline (10)MajGov & -0.008 & -0.131 & 0.054 & 0.018 & -0.074 & 0.096 & -0.045 & -0.037 & -0.038 & 1 & 0.148 & -0.160 & -0.014 & 0.121 & -0.003 & -0.033 \\
\hline (11)TimeOffice & -0.183 & -0.043 & -0.073 & -0.201 & -0.213 & -0.098 & -0.121 & -0.009 & 0.023 & 0.150 & 1 & -0.372 & -0.091 & 0.168 & 0.041 & -0.224 \\
\hline (12)Democracy & 0.591 & -0.047 & 0.475 & 0.535 & 0.609 & 0.432 & 0.291 & 0.145 & 0.059 & -0.106 & -0.451 & 1 & 0.499 & -0.072 & -0.254 & 0.465 \\
\hline (13)LnGDPpc & 0.674 & -0.337 & 0.810 & 0.549 & 0.651 & 0.562 & 0.244 & 0.101 & 0.055 & 0.045 & -0.111 & 0.471 & 1 & 0.211 & -0.365 & 0.832 \\
\hline (14)Trade & 0.356 & -0.004 & 0.314 & 0.180 & 0.371 & 0.395 & -0.015 & 0.084 & -0.018 & 0.124 & 0.245 & -0.054 & 0.298 & 1 & -0.107 & 0.213 \\
\hline (15)FinCrisis & -0.387 & 0.004 & -0.344 & -0.307 & -0.347 & -0.332 & -0.076 & -0.059 & -0.030 & 0.016 & 0.097 & -0.205 & -0.352 & -0.090 & 1 & -0.385 \\
\hline (16)Education & 0.654 & -0.265 & 0.745 & 0.529 & 0.610 & 0.576 & 0.193 & 0.131 & 0.063 & -0.027 & -0.219 & 0.457 & 0.846 & 0.226 & -0.371 & 1 \\
\hline
\end{tabular}

Notes: See Table 1. Upper-triangle (lower-triangle) shows the correlations for the entire sample period (for 2000 onwards). 
Table A.3. Panel unit root tests

\begin{tabular}{|c|c|c|c|c|}
\hline \multirow[b]{2}{*}{ Variable } & \multicolumn{4}{|c|}{ ADF Fisher-type tests } \\
\hline & $P$ & $Z$ & $L^{*}$ & $P m$ \\
\hline \multicolumn{5}{|l|}{2000 onwards } \\
\hline EconFreedom & $735.43(0.000)$ & $-17.42(0.000)$ & $-18.05(0.000)$ & $22.99(0.000)$ \\
\hline SizeGov & $763.75(0.000)$ & $-17.84(0.000)$ & $-18.79(0.000)$ & $24.29(0.000)$ \\
\hline LegalSystem & $720.14(0.000)$ & $-17.18(0.000)$ & $-17.63(0.000)$ & $22.28(0.000)$ \\
\hline SoundMoney & $722.44(0.000)$ & $-17.06(0000)$ & $-17.63(0.000)$ & $22.39(0.000)$ \\
\hline FreedomTrade & $703.99(0.000)$ & $-16.51(0.000)$ & $-16.98(0.000)$ & $21.54(0.000)$ \\
\hline Regulation & $853.33(0.000)$ & $-19.18(0.000)$ & $-20.96(0.000)$ & $28.42(0.000)$ \\
\hline \multicolumn{5}{|c|}{ Total time period } \\
\hline EconFreedom & $857.40(0.000)$ & $-19.65(0.000)$ & $-21.20(0.000)$ & $28.60(0.000)$ \\
\hline SizeGov & $938.16(0.000)$ & $-23.94(0.000)$ & $-28.49(0.000)$ & $41.53(0.000)$ \\
\hline LegalSystem & $960.91(0.000)$ & $-21.46(0.000)$ & $-23.98(0.000)$ & $33.37(0.000)$ \\
\hline SoundMoney & $891.40(0.000)$ & $-20.48(0.000)$ & $-22.20(0.000)$ & $30.17(0.000)$ \\
\hline FreedomTrade & $953.62(0.000)$ & $-20.72(0.000)$ & $-23.49(0.000)$ & $33.03(0.000)$ \\
\hline Regulation & $981.07(0.000)$ & $-22.99(0.000)$ & $-26.96(0.000)$ & $38.90(0.000)$ \\
\hline TimeOffice & $872.28(0.000)$ & $-19.96(0.000)$ & $-23.41(0.000)$ & $33.61(0.000)$ \\
\hline Democracy & $593.69(0.000)$ & $-11.69(0.000)$ & $-14.06(0.000)$ & $19.29(0.000)$ \\
\hline $\operatorname{LnGDPpc}$ & $950.43(0.000)$ & $-18.10(0.000)$ & $-20.04(0.000)$ & $27.42(0.000)$ \\
\hline Trade & $935.31(0.000)$ & $-18.24(0.000)$ & $-20.02(0.000)$ & $26.97(0.000)$ \\
\hline Education & $825.75(0.000)$ & $-14.79(0.000)$ & $-17.03(0.000)$ & $24.45(0.000)$ \\
\hline
\end{tabular}

Notes: See Table 1. Four Fisher-type ADF unit-root test statistics are reported for the continuous variables only (the respective $p$-values are in parentheses): inverse chi-squared $P$; inverse normal $Z$; inverse $\operatorname{logit} L^{*}$; and the modified inverse chi-squared Pm. One lag of the series is used in the ADF regressions, but different lag structures produce similar results. Phillips-Perron unit-root tests were also considered, but the conclusions remain unchanged (those results are not reported here but are available upon request). These tests are preferred due to the fact of the panel is not strongly balanced. 
Table A.4. Five-year time spans estimations (1975-2015)

\begin{tabular}{|c|c|c|c|c|c|c|c|c|}
\hline & \multicolumn{3}{|c|}{ EconFreedom } & \multirow{2}{*}{$\begin{array}{c}\text { GovSize } \\
\text { (4) }\end{array}$} & \multirow{2}{*}{$\frac{\text { LegalSystem }}{(5)}$} & \multirow{2}{*}{$\begin{array}{c}\text { SoundMoney } \\
(6)\end{array}$} & \multirow{2}{*}{$\frac{\text { Freed'Trade }}{(7)}$} & \multirow{2}{*}{$\frac{\text { Regulation }}{(8)}$} \\
\hline & (1) & (2) & (3) & & & & & \\
\hline L.DepVar & $\begin{array}{c}0.4126 * * * \\
(0.0829)\end{array}$ & $\begin{array}{c}0.5017 * * * \\
(0.0702)\end{array}$ & $\begin{array}{c}0.4986 * * * \\
(0.0698)\end{array}$ & $\begin{array}{c}0.5534 * * * \\
(0.0848)\end{array}$ & $\begin{array}{c}0.4910 * * * \\
(0.0726)\end{array}$ & $\begin{array}{c}0.4937 * * * \\
(0.0680)\end{array}$ & $\begin{array}{c}0.5100 * * * \\
(0.0699)\end{array}$ & $\begin{array}{c}0.4687 * * * \\
(0.0888)\end{array}$ \\
\hline Right & $\begin{array}{c}0.1213 * * \\
(0.0608)\end{array}$ & $\begin{array}{c}0.1123 * * \\
(0.0569)\end{array}$ & $\begin{array}{c}0.1947 * * \\
(0.0910)\end{array}$ & $\begin{array}{c}0.1067 \\
(0.1109)\end{array}$ & $\begin{array}{l}-0.0317 \\
(0.1227)\end{array}$ & $\begin{array}{l}0.1350^{*} \\
(0.0813)\end{array}$ & $\begin{array}{l}0.1141^{*} \\
(0.0690)\end{array}$ & $\begin{array}{c}0.1886 * * \\
(0.0828)\end{array}$ \\
\hline Election & $\begin{array}{c}0.0964 \\
(0.0642)\end{array}$ & $\begin{array}{c}0.0984 \\
(0.0803)\end{array}$ & $\begin{array}{c}0.0910 \\
(0.0774)\end{array}$ & $\begin{array}{c}0.0309 \\
(0.1837)\end{array}$ & $\begin{array}{c}-0.0746 \\
(0.1381)\end{array}$ & $\begin{array}{c}0.2310 \\
(0.2234)\end{array}$ & $\begin{array}{c}0.1551 \\
(0.1579)\end{array}$ & $\begin{array}{c}0.0447 \\
(0.1061)\end{array}$ \\
\hline MajGov & $\begin{array}{l}-0.0252 \\
(0.0675)\end{array}$ & $\begin{array}{l}-0.0578 \\
(0.0641)\end{array}$ & $\begin{array}{l}-0.0487 \\
(0.0598)\end{array}$ & $\begin{array}{l}-0.2041 \\
(0.1468)\end{array}$ & $\begin{array}{l}-0.1164 \\
(0.1062)\end{array}$ & $\begin{array}{l}-0.2125 \\
(0.1831)\end{array}$ & $\begin{array}{c}0.0592 \\
(0.1390)\end{array}$ & $\begin{array}{l}0.1802^{*} \\
(0.0988)\end{array}$ \\
\hline Democracy & $\begin{array}{l}-0.0018 \\
(0.0017)\end{array}$ & $\begin{array}{l}-0.0002 \\
(0.0029)\end{array}$ & $\begin{array}{c}0.0002 \\
(0.0025)\end{array}$ & $\begin{array}{l}-0.0006 \\
(0.0029)\end{array}$ & $\begin{array}{c}0.0095 * * * \\
(0.0024)\end{array}$ & $\begin{array}{l}-0.0005 \\
(0.0069)\end{array}$ & $\begin{array}{c}0.0061 * * \\
(0.0026)\end{array}$ & $\begin{array}{l}-0.0007 \\
(0.0025)\end{array}$ \\
\hline$L n G D P p c$ & $\begin{array}{c}0.0259 \\
(0.0729)\end{array}$ & $\begin{array}{c}0.1198^{* * *} \\
(0.0401)\end{array}$ & $\begin{array}{l}0.0764^{*} \\
(0.0460)\end{array}$ & $\begin{array}{c}-0.2397 * * * \\
(0.0713)\end{array}$ & $\begin{array}{c}0.3997 * * * \\
(0.0823)\end{array}$ & $\begin{array}{c}0.1088 \\
(0.0730)\end{array}$ & $\begin{array}{c}0.2273 * * * \\
(0.0515)\end{array}$ & $\begin{array}{c}0.1382 * * * \\
(0.0435)\end{array}$ \\
\hline Trade & $\begin{array}{c}0.0015^{* *} \\
(0.0006)\end{array}$ & $\begin{array}{c}0.0017 * * * \\
(0.0006)\end{array}$ & $\begin{array}{c}0.0019 * * \\
(0.0008)\end{array}$ & $\begin{array}{c}0.0011 \\
(0.0017)\end{array}$ & $\begin{array}{c}0.0016 * * \\
(0.0007)\end{array}$ & $\begin{array}{c}0.0016 \\
(0.0010)\end{array}$ & $\begin{array}{c}0.0024 * * * \\
(0.0008)\end{array}$ & $\begin{array}{c}0.0029 * * * \\
(0.0010)\end{array}$ \\
\hline FinCrisis & $\begin{array}{c}-0.3663 * * * \\
(0.0945)\end{array}$ & $\begin{array}{c}-0.4063 * * * \\
(0.0872)\end{array}$ & $\begin{array}{c}-0.3883 * * * \\
(0.0822)\end{array}$ & $\begin{array}{l}-0.1771 \\
(0.1728)\end{array}$ & $\begin{array}{c}-0.5013^{* * * *} \\
(0.1493)\end{array}$ & $\begin{array}{c}-1.1671 * * * \\
(0.2485)\end{array}$ & $\begin{array}{l}-0.1697 \\
(0.1795)\end{array}$ & $\begin{array}{c}-0.2469^{* *} \\
(0.1172)\end{array}$ \\
\hline Education & $\begin{array}{c}1.2902 * * * \\
(0.4427)\end{array}$ & & & & & & & \\
\hline$O E C D$ & & & $\begin{array}{l}0.1967^{*} \\
(0.1112)\end{array}$ & & & & & \\
\hline OECD $\times$ Right & & & $\begin{array}{l}-0.1280 \\
(0.1491)\end{array}$ & & & & & \\
\hline Observations & 334 & 464 & 464 & 467 & 460 & 471 & 461 & 463 \\
\hline Countries & 104 & 105 & 105 & 105 & 105 & 105 & 105 & 105 \\
\hline Instruments & 85 & 87 & 89 & 87 & 87 & 87 & 87 & 87 \\
\hline AR1 & 0.0092 & 0.0001 & 0.0000 & 0.0000 & 0.0003 & 0.0002 & 0.0077 & 0.0014 \\
\hline AR2 & 0.4837 & 0.8435 & 0.9927 & 0.4742 & 0.2155 & 0.0695 & 0.1834 & 0.6509 \\
\hline Hansen & 0.3024 & 0.3990 & 0.3606 & 0.2995 & 0.2142 & 0.1588 & 0.2909 & 0.2411 \\
\hline Diff-Hansen1 & 0.1002 & 0.4449 & 0.4274 & 0.3599 & 0.1592 & 0.1014 & 0.3693 & 0.1912 \\
\hline Diff-Hansen2 & 0.9662 & 0.3398 & 0.2939 & 0.2834 & 0.5576 & 0.6076 & 0.2516 & 0.5319 \\
\hline
\end{tabular}

Notes: See Table 1 for the definition of the variables. L.DepVar corresponds to the lag of the dependent variable for the respective area of economic freedom. Time-effects are accounted for using year dummies (not reported here). Two-step system-GMM estimations using robust standard errors corrected for finite samples (robust standard errors in parenthesis). Significance levels at which the null hypothesis is rejected: ***, $1 \%$;*, $5 \%$; and *, $10 \%$. The lag of the dependent variable and Democracy are treated as endogenous in the GMM estimations; the respective lagged values and the other explanatory variables are used as instruments in the first-difference equation and their differences are used in the levels equation. As the number of time periods is much smaller, the same happens with the number of instruments so there is no need to collapse them. The values reported for AR(1) and AR(2) are the $p$-values of the Arellano-Bond tests for first and second order auto-correlated disturbances in the first differences equations. The Hansen test reports the $p$-value for the null hypothesis of instrument validity; Diff-Hansen1 tests the exogeneity of the instruments used in the level part (of the system) as a whole. Diff-Hansen 2 tests the exogeneity of the lagged level of economic freedom used as an instrument in the level part. 
Table A.5. Averages over legislative periods (1975-2015)

\begin{tabular}{|c|c|c|c|c|c|c|c|c|}
\hline & \multicolumn{3}{|c|}{ EconFreedom } & \multirow{2}{*}{$\begin{array}{c}\text { GovSize } \\
(4) \\
\end{array}$} & \multirow{2}{*}{$\frac{\text { LegalSystem }}{(5)}$} & \multirow{2}{*}{$\frac{\text { SoundMoney }}{(6)}$} & \multirow{2}{*}{$\frac{\text { Freed'Trade }}{(7)}$} & \multirow{2}{*}{$\begin{array}{c}\text { Regulation } \\
(8) \\
\end{array}$} \\
\hline & (1) & (2) & (3) & & & & & \\
\hline L.DepVar & $\begin{array}{c}0.1579 * * \\
(0.0711)\end{array}$ & $\begin{array}{c}0.1691 * * \\
(0.0660)\end{array}$ & $\begin{array}{c}0.1522 * * * \\
(0.0571)\end{array}$ & $\begin{array}{c}0.1547 * * \\
(0.0722)\end{array}$ & $\begin{array}{c}0.1646 * * \\
(0.0767)\end{array}$ & $\begin{array}{l}0.1041^{*} \\
(0.0568)\end{array}$ & $\begin{array}{c}0.1528 * * \\
(0.0638)\end{array}$ & $\begin{array}{c}0.1970 * * * \\
(0.0517)\end{array}$ \\
\hline Right & $\begin{array}{c}0.1398 * * \\
(0.0554)\end{array}$ & $\begin{array}{c}0.1279 * * \\
(0.0508)\end{array}$ & $\begin{array}{c}0.1402 * * \\
(0.0583)\end{array}$ & $\begin{array}{c}0.0128 \\
(0.0836)\end{array}$ & $\begin{array}{c}0.0656 \\
(0.0829)\end{array}$ & $\begin{array}{l}0.1401^{*} \\
(0.0730)\end{array}$ & $\begin{array}{l}0.1112^{*} \\
(0.0627)\end{array}$ & $\begin{array}{c}0.2303 * * * \\
(0.0693)\end{array}$ \\
\hline Election & $\begin{array}{c}0.0462 \\
(0.0810)\end{array}$ & $\begin{array}{c}0.0709 \\
(0.0575)\end{array}$ & $\begin{array}{c}0.0801 \\
(0.0614)\end{array}$ & $\begin{array}{c}0.2488 \\
(0.1858)\end{array}$ & $\begin{array}{c}-0.0687 \\
(0.0615)\end{array}$ & $\begin{array}{c}0.0717 \\
(0.1038)\end{array}$ & $\begin{array}{c}0.0470 \\
(0.0669)\end{array}$ & $\begin{array}{c}0.0058 \\
(0.0622)\end{array}$ \\
\hline MajGov & $\begin{array}{l}-0.1166 \\
(0.0768)\end{array}$ & $\begin{array}{l}-0.1066^{*} \\
(0.0577)\end{array}$ & $\begin{array}{l}-0.1043^{*} \\
(0.0602)\end{array}$ & $\begin{array}{l}-0.1215 \\
(0.1020)\end{array}$ & $\begin{array}{l}-0.0114 \\
(0.0993)\end{array}$ & $\begin{array}{c}-0.1836^{*} \\
(0.1016)\end{array}$ & $\begin{array}{l}-0.2212 \\
(0.1826)\end{array}$ & $\begin{array}{l}-0.0305 \\
(0.0769)\end{array}$ \\
\hline Democracy & $\begin{array}{l}0.0075^{*} \\
(0.0042)\end{array}$ & $\begin{array}{c}0.0079 * * \\
(0.0035)\end{array}$ & $\begin{array}{c}0.0076^{* *} \\
(0.0032)\end{array}$ & $\begin{array}{c}0.0042 \\
(0.0065)\end{array}$ & $\begin{array}{l}0.0070^{*} \\
(0.0041)\end{array}$ & $\begin{array}{c}0.0081 \\
(0.0044)\end{array}$ & $\begin{array}{c}0.0166^{* * * *} \\
(0.0063)\end{array}$ & $\begin{array}{c}-0.0001 \\
(0.0052)\end{array}$ \\
\hline $\operatorname{Ln} G D P p c$ & $\begin{array}{c}0.1736^{* *} \\
(0.0757)\end{array}$ & $\begin{array}{c}0.2637 * * * \\
(0.0342)\end{array}$ & $\begin{array}{c}0.2384^{* * *} * \\
(0.0596)\end{array}$ & $\begin{array}{c}-0.3789 * * * \\
(0.0732)\end{array}$ & $\begin{array}{c}0.7791 * * * \\
(0.1081)\end{array}$ & $\begin{array}{c}0.4206^{* * *} \\
(0.0543)\end{array}$ & $\begin{array}{c}0.3513 * * * \\
(0.0362)\end{array}$ & $\begin{array}{c}0.2256^{* * *} * \\
(0.0491)\end{array}$ \\
\hline Trade & $\begin{array}{c}0.0024 * * \\
(0.0012)\end{array}$ & $\begin{array}{c}0.0023 * * \\
(0.0010)\end{array}$ & $\begin{array}{c}0.0026^{* *} \\
(0.0011)\end{array}$ & $\begin{array}{c}0.0016 \\
(0.0029)\end{array}$ & $\begin{array}{c}0.0011 \\
(0.0008)\end{array}$ & $\begin{array}{c}0.0013 \\
(0.0009)\end{array}$ & $\begin{array}{c}0.0031 * * * \\
(0.0008)\end{array}$ & $\begin{array}{c}0.0037 * * * \\
(0.0010)\end{array}$ \\
\hline FinCrisis & $\begin{array}{c}-0.3086^{* *} \\
(0.1422)\end{array}$ & $\begin{array}{c}-0.3174 * * * \\
(0.0586)\end{array}$ & $\begin{array}{c}-0.3116^{* * *} \\
(0.0571)\end{array}$ & $\begin{array}{c}-0.2102^{* * *} \\
(0.0913)\end{array}$ & $\begin{array}{c}-0.1823 * * * \\
(0.0666)\end{array}$ & $\begin{array}{c}-0.4499 * * * \\
(0.1416)\end{array}$ & $\begin{array}{c}-0.3873 * * * \\
(0.0716)\end{array}$ & $\begin{array}{c}-0.2638 * * * \\
(0.0700)\end{array}$ \\
\hline Education & $\begin{array}{c}0.9458 \\
(0.6814)\end{array}$ & & & & & & & \\
\hline$O E C D$ & & & $\begin{array}{l}0.1916^{*} \\
(0.1139)\end{array}$ & & & & & \\
\hline$O E C D \times R i g h t$ & & & $\begin{array}{c}-0.0198 \\
(0.1145) \\
\end{array}$ & & & & & \\
\hline Observations & 425 & 532 & 532 & 532 & 532 & 532 & 532 & 532 \\
\hline Countries & 104 & 105 & 105 & 105 & 105 & 105 & 105 & 105 \\
\hline Instruments & 84 & 88 & 90 & 88 & 88 & 88 & 88 & 88 \\
\hline AR1 & 0.0065 & 0.0009 & 0.0009 & 0.0000 & 0.0002 & 0.0008 & 0.0004 & 0.0000 \\
\hline AR2 & 0.6936 & 0.2729 & 0.3104 & 0.1239 & 0.7782 & 0.8974 & 0.5338 & 0.4608 \\
\hline Hansen & 0.4866 & 0.6367 & 0.6282 & 0.6914 & 0.8767 & 0.9026 & 0.9415 & 0.6192 \\
\hline Diff-Hansen1 & 0.4909 & 0.4596 & 0.4580 & 0.8333 & 0.8836 & 0.6223 & 0.7854 & 0.3527 \\
\hline Diff-Hansen2 & 0.4538 & 0.7430 & 0.7318 & 0.3251 & 0.6095 & 0.9634 & 0.9347 & 0.8428 \\
\hline
\end{tabular}

Notes: See Table 1 for the definition of the variables. A legislative period corresponds to the time during which there is no change in the government/cabinet. L.DepVar corresponds to the lag of the dependent variable for the respective area of economic freedom. Time-effects are accounted for using decade dummies (not reported here). Two-step system-GMM estimations using robust standard errors corrected for finite samples (robust standard errors in parenthesis). Significance levels at which the null hypothesis is rejected: ***, $1 \%$; **, 5\%; and *, 10\%. The lag of the dependent variable and Democracy are treated as endogenous in the GMM estimations; the respective lagged values and the other explanatory variables are used as instruments in the first-difference equation and their differences are used in the levels equation. As the number of time periods is much smaller, the same happens with the number of instruments so there is no need to collapse them. The values reported for AR(1) and $\operatorname{AR}(2)$ are the $p$-values of the Arellano-Bond tests for first and second order auto-correlated disturbances in the first differences equations. The Hansen test reports the $p$-value for the null hypothesis of instrument validity; Diff-Hansen1 tests the exogeneity of the instruments used in the level part (of the system) as a whole. Diff-Hansen 2 tests the exogeneity of the lagged level of economic freedom used as an instrument in the level part. 